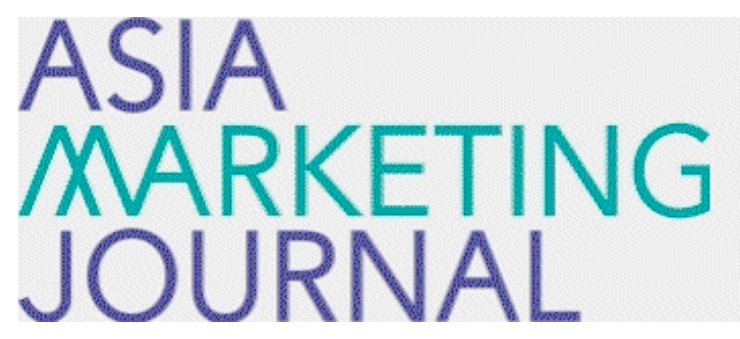

ASIA MARKETING JOURNAL

Volume 14 | Issue 2

Article 5

7-30-2012

\title{
독특성 추구성향과 호기심이 아트 콜라보레이션 제품에 대한 소비 자의 감정에 미치는 영향
}

Seon Hee Ju

Dong Mo Koo

Follow this and additional works at: https://amj.kma.re.kr/journal

Part of the Marketing Commons

\section{Recommended Citation}

$\mathrm{Ju}$, Seon Hee and Koo, Dong Mo (2012) "독특성 추구성향과 호기심이 아트 콜라보레이션 제품에 대한 소비 자의 감정에 미치는 영향," Asia Marketing Journal: Vol. 14 : Iss. 2 , Article 5.

Available at: https://doi.org/10.53728/2765-6500.1481

This Article is brought to you for free and open access by Asia Marketing Journal. It has been accepted for inclusion in Asia Marketing Journal by an authorized editor of Asia Marketing Journal. 


\title{
독특성 추구성향과 호기심이 아트 콜라보레이션 제품에 대한 소비자의 감정에 미치는 영향: 성별에 따른 조절효과
}

\section{The Effect of Curiosity and Need for Uniqueness on Emotional Responses to Art Collaborated Products including Moderating Effect of Gender}

\author{
주 선 희 $(\mathrm{Seon} \mathrm{Hee} \mathrm{Ju})^{*}$ \\ 구 동 모(Dong-Mo $\mathrm{Koo})^{* *}$
}

연구목적 - 최근 기업에서 마케팅이나 광고를 할 때 아트를 활용하여 기존의 명화나 아티스트들과 협업한 새로운 작품을 제품에 접목하거나. 마케팅에 활용하는 경우가 늘어나는 추세이다. 아트 콜 라보레이션 제품을 새로운 자극으로 생각하고, 자극에 민감하게 반응하는 독특성 추구성향과 호 기심이 많은 소비자일수록 아트 콜라보레이션 제품에 대한 호감도가 증가할 것으로 본다. 따라서 본 연구는 아트마케팅에 대해 전반적으로 살펴보고. 개인특성인 호기심과 독특성 추구성향이 아 트 콜라보레이션 제품에 대한 소비자의 감정에 미치는 영향과 구매의도에 미치는 영향을 알아 보 았다. 그리고 성별에 따라 개인특성과 소비자의 감정 사이에 미치는 영향은 차이가 있을 것이라 예측하고 성별의 조절효과를 살펴보았다.

연구결과 - 호기심은 긍정적 감정에 정의 영향을 미치며. 환기와 부정적 감정에는 영향을 미치지 않 는 것으로 나타났다. 독특성 추구성향 중 창의적 선택은 긍정적 감정과 환기에 정의 영향을 미치 며. 부정적 감정에 부의 영향을 미치는 것으로 나타났다. 독특성 추구성향 중 비대중적 선택은 긍 정적 감정과 부정적 감정에는 영향이 없는 것으로 나타났으며. 환기에는 유의한 것으로 나타났다. 그리고 독특성 추구성향 중 유사성 회피는 소비자의 감정에 어떠한 영향도 미치지 않는 것으로 나타났다. 그리고 성별에 따른 차이를 살펴본 결과, 창의적 선택과 부정적 감정 사이와 비대중적 선택과 부정적 감정 사이에서만 남녀 간의 차이가 유의한 것으로 나타났다.

시사점 - 소비자의 호기심을 유발시킬 수 있는 새로운 디자인이나 전략을 시도하면 효과적일 것을 알 수 있으며, 독특성 욕구 중 자신의 정체성을 표현하고자 하는 욕구가 높은 사람이 아트 제품 에 대하여 감정의 영향을 많이 받음을 알 수 있다. 따라서 지속적으로 예술가들과 콜라보레이션 활동을 통해 소비자의 감성을 자극하는 제품을 생산해야 할 것이다. 성별에 따른 큰 차이가 없으 므로 남녀 구분없이 모두의 관심을 끌 수 있는 마케팅을 해도 무관하다는 것을 알 수 있다.

핵심개념: 아트 마케팅. 호기심. 독특성 추구성향, 소비자 감정. 구매의도, 성별

* 경북대학교 박사수료(jshjshs@knu.ac.kr). 교신저자

** 경북대학교. 교수(unlimited@knu.ac.kr) 


\section{I. 서 론}

최근 경제적 발전으로 소비자의 생활수준과 삶의 질이 높아지면서 소비자의 소비수준도 높 아졌다. 높아진 소비수준은 소비자의 욕구를 다 양하게 만들었으며, 소비자로 하여금 여러 미디 어로 다양하고 세부적인 정보를 제공받을 수 있도록 하였다. 따라서 기업은 소비자의 욕구를 충족시키는 제품을 생산하기가 점점 힘들어졌 으며. 치열하고 복잡한 마케팅 환경에서 살아남 기가 어려워지고 있다. 그 동안 기업들은 기술 개발을 통해 제품을 차별시켜왔지만 기술의 진 화로 인해 기업별 기술 격차가 줄어들었기 때 문에 기술을 통한 차별화는 더 이상 의미가 없 어졌다. 따라서 기업은 기술 이외에 소비자의 욕구와 관심을 끌 수 있는 즉, 소비자의 감성을 자극하는 요소를 찾아야 하는 실정이다.

기존에는 제품의 기능이나 성능 등이 구매시 고려요인에 큰 비중을 차지했지만 제품의 기술 이 큰 차별화가 되지 않는 상황에서 소비자들 은 제품의 획기적이고 신선한 디자인이나 이미 지에 관심을 가지게 되었다. 젊은 세대들은 트 렌드에 벗어나지 않으면서 남들에게 자신을 표 현할 수 있는 제품을 선호한다. 가격이나 기능 외에도 심미적 또는 감성적 욕구를 자극할 수 있는 디자인 요인을 구매의사결정시에 중요하 게 여기고 있다. 따라서 기업들은 자신을 표현 하고자 하는 소비자의 관심을 끌기 위해서 감 성마케팅에 관심을 가지게 되었다. 특히 아트라 는 주제는 소비자의 감성을 자극하기에 적절한 소재로 아티스트들과 협업활동을 통해 제품의 디자인을 개발하여 신제품을 출시하고 있다. 이
를 아트 콜라보레이션이라 한다. 소비자들은 제 품을 단순히 필요에 의하여 구매하는 것이 아 니라 문화와 예술을 일상생활에서도 접할 수 있다는 개넘으로 발전시켜 아트 콜라보레이션 제품을 선호하고 있다. 제품을 통해 감성적 욕 구와 상징적 욕구를 충족시키고자 하며 사소한 제품 하나라도 디자인을 고려하여 구매하는 것 을 선호한다. 아트마케팅은 현재 활발히 이루어 지고 있으며. 기업과 소비자의 호응을 얻고 있 다. 에비앙의 물병디자인에서 화장품 용기, 패 션잡화, 가전제품, 자동차까지 다양한 분야에서 아트 콜라보레이션에 관심을 가지고 계속적으 로 아트제품을 출시하고 있다. 화가, 패션디자 이너, 사진작가 등의 아티스트들과 기업이 만나 다양한 분야의 제품에서 기존의 개념을 탈피하 여 아트적 요소를 가미한 제품을 생산하거나 아트적 요소를 활용하여 광고함으로써 소비자 의 감성을 자극하고 있다. 아트 콜라보레이션은 기업의 이미지 차원에서 작가를 후원해주는 것 이 아닌 아티스트가 가진 크리에이티브한 상상 력을 아티스트의 브랜드 가치로 인정하여 파트 너십을 구축한 제휴 및 협력이다. 공동 작업의 범주는 기술의 개발에서부터 디자인, 연계 제품 의 생산에 이르기까지 그 범위가 상당히 넓은 편이다(김민선, 2010). 따라서 아트 콜라보레이 션 제품은 소비자의 감성적 욕구 또는 문화적 욕구를 만족시키는 동시에 제품의 가치도 상승 시키게 되며, 아트 마케팅은 아트를 이용하여 제품의 이미지와 인지도를 높이는 고도의 감성 마케팅 전략이라 할 수 있다.

아트란 우리가 작품을 감상하고 소비하는 과 정을 통해 경험적으로 정의내리는 지극히 주관 적이면서 추상적인 개념을 뜻한다(유미연. 2008), 
이는 사람들의 감정을 자극하는데 중요한 역할 을 한다. 아트는 시각이나 다른 감각의 형태를 통해 사람들의 감정에 영향을 미친다(Sporre, 2003). Bloch(1995)의 연구에 의하면 제품의 형 태나 디자인은 시장에서의 성공을 결정짓는 중 요한 요인이라고 한다. 그 이유는 좋은 디자인 은 소비자들을 매혹시키며 소비자와 유대감을 형성하며. 제품의 가치를 더하기 때문이다. 따 라서 제품의 디자인은 소비자의 심리적 반응과 행동적 반응에 영향을 미칠 수 있기 때문에 소 비자의 구매결정에서 중요한 요인이 될 수 있다. Fillis(2011)의 연구에서도 아트는 인간의 감 각. 마음, 영혼을 자극시키는 요인으로, 아트를 활용하면 인간의 행동을 이해할 수 있을 뿐만 아니라 인간의 행동을 유도하는데 용이할 수 있다고 한다. 아트를 이해하고 받아들이는 정도 는 개인마다 차이가 있으며. 개인특성에 따라 아트를 받아들이고 이해하는 정도는 다르다.

인간은 일반적으로 큰 범위에서는 보면 사람 들과 무리를 지어 준거집단을 만들며 소속감을 느끼고자 하지만. 그 준거집단 안에서는 남들과 는 다르게 보이고자 하는 욕구가 있다. 이러한 욕구는 독특성을 표현하고자 하는 성향과 남들 과는 다름을 지각하는 호기심 욕구를 기반으로 한다. 남들과는 다르게 자신을 표현하고자 하는 욕구가 강한 소비자는 아트제품에 대해 선호하 는 성향이 강할 수 있다. 아트제품은 희소성과 독창적인 성격을 가지고 있기 때문에 자신만의 정체성을 표현하는데 도움을 줄 수 있기 때문 이다. 따라서 수많은 개인특성 중에서도 호기심 과 독특성 추구성향에 대해 살펴보고자 한다. 호기심과 독특성 추구성향에 따라 아트 콜라보 레이션 제품에 대해 느끼는 감정이 달라질 것
이라고 본다. 그리고 여러 개인 특성이 구매의 사결정에 영향을 미치겠지만. 아트 콜라보레이 션이라는 제품은 새로운 시도로 독특성 욕구. 호기심. 혁신성. 신기성 욕구 등이 높은 소비자 들이 더 빨리 시도하게 된다. 전경숙, 박혜정 (2005)의 연구에서 독특성 욕구가 패션성향과 구매의도에 미치는 영향을 살펴보았다. 독특성 추구성향이 높은 사람은 패션성향과 구매의도 에도 영향을 미치기 때문에 아트 콜라보레이션 제품을 선택. 구매할 가능성이 높다고 예측할 수 있다고 하였다. 기존의 제품에서 보다 새로 운 시도를 해보고자 하는 욕구가 높은 사람이 아트 콜라보레이션 제품을 더 호의적으로 보고 구매할 가능성이 높다고 볼 수 있다. 새로운 시 도를 하는 성향이 높은 사람이 독특성 추구성 향이 높으며, 호기심이 높은 사람으로 보고 있다. 따라서 본 연구에서는 호기심이 많고 적음에 따라. 그리고 독특성 추구성향이 높거나 낮음에 따라 아트 콜라보레이션 제품에 대한 감정도 각각 다를 것이며. 구매의도 역시 달라질 것으 로 보고 이를 연구하고자 한다. 그리고 성별에 따라 호기심과 독특성 추구성향, 소비자의 감정 사이에 미치는 영향도 달라질 것으로 본다. 따 라서 본 연구의 구체적 목적은 첫째, 소비자의 개인특성 중 호기심과 독특성 추구성향에 대해 알아보고, 개인특성이 아트 콜라보레이션 제품 에 대한 소비자의 감정에 미치는 영향을 알아 보고자 한다. 둘째, 소비자의 감정이 아트 콜라 보레이션 제품의 구매의도에 미치는 영향에 대 해 알아보고자 한다. 셋째. 성별에 따른 개인특 성인 호기심. 독특성 추구성향과 소비자의 감정 간의 조절적 영향에 대해 알아본다. 


\section{II. 이론적 고찰}

\section{1 아트 마케팅}

아트 마케팅이란 소비자에게 제공하는 제품의 표현양식이나 제작. 마케팅 영역에서 문화예술 의 예술성을 빌려 다른 기업과 차별화된 예술 코드를 심음으로써 예술융합상품으로 전환, 경 쟁력을 확보하는 것을 말한다(윤지연, 2007). 김민선(2010)의 연구에서는 아트 마케팅을 소 비자에게 제공하는 제품의 제작. 마케팅 등 전 영역에 있어 문화와 예술을 접목하여 예술 코드 를 제시하여 경쟁력을 확보하는 것이라고 한다.

아트와 제품이 만남으로써 고급스러움을 창조 하는 시너지 효과를 생성한다. Hagtvedt and Patrick(2008)에 의하면 아트마케팅은 가구를 예술적으로 디자인하는 것, 셔츠에 그림을 그리 는 것과 같이 제품과 통합체가 되는 것을 뜻한 다고 한다. 즉, 일반 제품에 아트 디자인 요소 로 가미했을 때 소비자는 그 제품을 고급제품 으로 인식하고 긍정적인 평가를 내린다. 주로 고급 패션 브랜드를 중심으로 전개된 아트마케 팅은 점차 확대되어 현재 산업 전반에서 이루 어지고 있다. 소수의 특정 계층만의 문화로 여 겨지던 예술을 우리의 생활에 친숙하도록 제품 이나 브랜드에 접목시킴으로써 소비자의 문화 예술에 대한 열망을 충족시키면서 큰 호응을 얻고 있다(이동철 외, 2008: 이경화 2008: 김정 현. 2009).

아트 마케팅은 비즈니스와 문화가 연관된 폭 넓은 범주에서 설명할 수 있다(Veryzer, 1999). 아트 마케팅의 시작은 문화예술의 후원을 통해
사회공헌을 목적으로 하는 소극적인 마케팅에 서 비롯되었으나. 현재 제품의 제작과 홍보 등 상업적 목적으로 적극적인 마케팅으로 변화하 고 있다. 기업은 예술분야의 고품격을 제품이나 마케팅에 도입하여 제품의 가치를 상승시키고 기업의 이미지를 제고시키고자 아트 마케팅을 도입하고 있다.

일반 제품에 아트적 요소를 가미함으로써 소 비자의 감성을 자극하여 구매결정시 선텍을 하 게 만드는 중요한 가치요인이 된 것이다. 따라 서 기업은 아트 마케팅을 기존의 문화예술 분 야에 지원 또는 후원의 개넘이 아니라 기업의 필요를 충족시켜주는 적극적인 마케팅의 하나 로 보며. 기업과 문화예술, 상호간의 이익을 위 한 마케팅으로 보고 있다.

아트 마케팅은 다양한 유형으로 표현되기 때 문에 몇 가지 유형으로 구분할 수 있다. 문신애 (2010)의 연구에서는 아트 콜라보레이션을 세 가지 유형으로 구분하고 있다. 첫째, 명화를 차 용하거나 미술작품을 패러디하여 활용하는 것. 둘째, 예술가와 헙업하여 새로운 제품을 생산하 거나 매장 인테리어, 전시공간을 꾸미는 것을 말한다. 셋째, 예술가의 작품 제작에 직접 참여 하는 경우를 말하는데 이 경우는 국내에서는 사례가 거의 드문 편이다.

아트 콜라보레이션은 고품격의 예술품을 이용 하거나 아티스트와 기업이 협력 또는 제휴를 통해 브랜드 가치를 제고하고 아티스트, 기업. 소비자가 상생할 수 있는 새로운 마케팅 패러 다임이다(김민선, 2010), 김한구, 정보희, 주우 진(2011)은 명화에 의해 증폭된 감정에 따라 환기 수준이 제품평가에 영향을 미치는 영향을 살펴보았다. 따라서 아트 콜라보레이션을 아티 
스트, 기업. 소비자 모두에게 가치있는 미래지 향적 마케팅 전략으로 보고 아트 콜라보레이션 제품에 대한 소비자의 반응을 연구하고자 한다.

\section{2 호기심}

호기심(Curiosity)은 새롭거나 복잡하고 애매모 호한 자극이나 상황에서 쉽게 유발된다. Berlyne (1957)의 연구에 의하면 사람은 새롭고, 복잡하 고, 애매모호한 자극에 직면하면 그것을 응시하 는 시간이 길어진다고 전한다. 즉, 개인이 어떤 자극에 호기심을 느끼면 시각. 청각. 미각, 후 각, 촉각 등의 감각기관으로 자극을 받아들인다 는 뜻이다. 호기심은 탐색적 행동 동기가 되는 새로운 감각적 경험과 새로운 정보나 지식을 획득하기 위한 욕구로 정의되기도 하며(Litman and Spielberger, 2003), 변화하는 환경 조건에 유연하게 적응할 수 있도록 도와주는 역할을 하기도 한다(Voss and Keller, 1983). 또한 Stell and Paden(1999)의 연구에서는 호기심을 개인 이 주위 환경에서 새로운 자극요인을 조사하고 탐색하며 그것을 긍정적으로 반응하는 정도로 정의한다. Loewenstein(1994)에 따르면. 호기심 은 아는 것과 알고자 하는 것 사이의 정보격차 를 좁히고자 하는 바람으로부터의 결과이며. 몰 랐던 정보를 획득하고자 하는 정보차이가 개인 의 호기심을 동기화시킨다고 한다.

호기심을 추구하는 사람들에게는 호기심이 유 발되는 과정이 유쾌함 그 자체이다. 호기심이 있는 사람이 우연히 새로운 제품에 대한 카탈 로그, 인터넷광고, 오프라인 매장의 판촉을 접 하게 되면 그 제품에 관심을 보이며, 제품에 대 한 정보를 더 탐색하고 조사하려 한다. 새로운
제품 판촉을 자극으로 지각하고 그것을 탐색하 는 과정을 즐기기 때문이다. 개인의 성향에 따 라 호기심을 느끼는 정도는 다를 것이고 그 호 기심 정도에 따라 소비자가 제품에 대한 감정 과 구매의도에 미치는 영향은 달라질 것으로 본다. 어떤 사람은 주위의 자극을 그낭 지나칠 수도 있지만 호기심이 많은 사람이라면 같은 자극에 노출되었다 할지라도 더 크게 지각하여 새로운 정보를 더 찾고자 할 것이며, 약간의 자 극에도 제품에 대한 관심도가 높아질 것이다. 따라서 본 연구에서는 개인의 호기심 정도에 따라 아트 콜라보레이션 제품에 대한 감정이 달라질 것이며. 아트 제품의 구매의도에도 영향 이 미칠 것으로 보고 연구하고자 한다.

\section{3 독특성 추구성향}

독특성 추구성향(Need for Uniqueness)은 한 개인이 다른 사람과의 차이를 느낄 수 있는 모 든 분야를 포함하고 있으며 대인상호관계를 위 주로 구성되어 있다(Snyder and Fromkin, 1980). 독특성 욕구 이론에 따르면, 일반적으로 개인은 다른 사람들과 매우 유사하다고 생각하는 상황 에서 다른 사람들과 다르게 보이고 싶은 욕구 가 발생한다(Tian, Bearden and Hunter, 2001). 사람들은 다양한 수준의 독특성이 있으며, 다양 한 방법으로 자신의 독특성을 표현하고자 하는 데. 자신의 색다른 행동이나 소유하고 있는 것 을 통해 독특성을 표출한다(Snyder and Fromkin, 1977). 독특성 표현은 다양하지만, 일반적으로 자신을 표현하고자 할 때 가장 보편적인 방법 이 물질적 표현이다. 이는 사회적 비난을 심하 게 받지 않으면서 자신을 남들과 차별화 할 수 
있기 때문이다(Snyder, 1992).

사람들이 독특성을 표현하는 이유는 사회적 존경을 얻기 위함이기도 하며, 주변인들에게 남 들과는 다른 자신만의 정체성을 표현하고자 함 이기도 하다. 따라서 평범하지 않는 제품을 구 매하거나 고의적으로 규범에 범하는 행동을 하 기도 하며, 색다른 시도를 하기도 한다. 이러한 독특성의 표현은 시간이 흐른 후에 혁신자 또 는 패션리더로서 사회적 존경을 얻기도 한다 (Tian, Beraden, Hunter, 2001). 고의적으로 규 범에 범하는 행동 등의 과격하게 독특성을 표 현하기도 하고 이와는 다르게 유행이라는 트렌 드를 추구하면서 작은 소품을 이용하여 자신만 의 독특성을 표현하는 등의 소극적인 표현을 한다. 사람마다 독특성 추구성향은 차이가 있으 며 그 수준은 다양하다.

Tian et al.(2001)는 소비자의 독특성 추구성향 을 세 차원으로 구분하였다. 창의적 선택(Creative choice), 비대중적 선택(Unpopular Choice), 유 사성 회피(Avoidance of similarity)로 구분하는데. 첫 번째 차원은 창의적 선택(Creative choice) 으로 다른 사람과 자신을 차별화하고 자신의 정체성을 표현하기 위해 소비재를 통해 자신만 의 스타일을 만들어 독특성을 표현하려는 성향 이다(Kron, 1983). 두 번째 차원은 비대중적 선 택(Unpopular Choice)은 집단의 규칙을 벗어난 제품을 선택하거나 사용하는 행동을 말한다. 세 번째 차원은 유사성 회피(Avoidance of similarity) 는 어떤 제품이나 브랜드가 다른 사람들에게 널리 알려지면 흥미나 관심을 잃어버리거나 구 매나 사용을 하지 않는 행동을 말한다.

본 연구는 Tian et al.(2001)의 연구를 바탕으 로 독특성 추구성향을 세 차원으로 구분한다.
자신의 정체성을 표현하고자 하는 창의적 선택, 규칙을 벗어나 돋보이고자 하는 비대중적 선택, 유사함을 피하고자 하는 유사성 회피의 다양한 독특성 추구성향에 따라 아트 콜라보레이션 제 품에 대한 소비자의 감정은 달라질 것으로 보 고 다음의 세 차원의 독특성 추구성향을 연구 하고자 한다.

\section{4 소비자의 감정과 구매의도}

감정반응은 Mehrabian and Russell(1974)의 Stimulus-Organism-Response모델을 기반으로 한 다. 감정은 Organism에 속하며. 지각적 또는 심 리적 느낌. 사고활동. 감정적 변화. 인지적 상태 를 말한다. 그리고 Organism은 사물에 대한 느 낌과 사고는 자극과 소비자의 반응사이를 매개 한다. 느낌과 사고를 통해 즐거움이나 환기, 통제 와 같은 감정반응이 나타나는데, 감정반응은 제 품이나 서비스 또는 환경에 대한 소비자의 반응 결과를 나타낼 수 있다. Donovan and Rossiter (1982)의 연구에서 소비자의 감정반응을 즐거 움(Pleasure), 환기(Arousal), 통제(Dominance) 로 구분한다. 즐거움(Pleasure)은 어떤 상황에 서 개인의 즐거움, 행복함. 만족감 정도를 뜻하 며, 환기(Arousal)는 어떤 상황에서 개인의 흥 분감, 자극적임, 민첩함, 활동성 정도를 뜻하며, 통제(Dominance)는 어떤 상황에서 개인 활동 의 자율적 통제가능성으로 언급된다(Donovan and Rossiter, 1982). Watson, Clark, Tellegen(1988) 은 소비자의 감정을 긍정적 감정과 부정적 감 정으로 구분하였으며. 서문식. 김상희(2004)의 연구에서는 감정반응을 긍정적 반응, 환기. 부 정적 반응, 통제로 구분한다. 많은 선행연구 
(Donovan, Rossiter, 1982: Eroglu, Machleit, Davis. 2003: Mummalaneni, 2005: Davis. Wang, Lindridge, 2008)에서 통제는 영향력이 없는 것 으로 나타났으며. Donovan. Rossiter(1982)의 연 구에서도 통제는 영향력이 없는 것으로 나타났 기 때문에 본 연구에서는 소비자의 감정을 통 제 차원을 제외한 긍정적 감정. 환기. 부정적 감정. 세 차원으로 구분하여 연구하고자 한다.

구매의도는 개인의 계획된 미래의 행동을 뜻 하는 것으로. Fishbein. Ajzen(1975)의 합리적 행동이론에 따르면, 자발적 행동의 경우 행동하 려는 의도에 따라 결정된다고 한다. 서문식. 김 상희(2002)의 인터넷 쇼핑몰 특성과 감정적 반 응과의 관계 연구에서 인터넷 쇼핑몰의 다양한 특성들이 소비자의 감정을 유발시키고 이러한 감정은 쇼핑몰 방문의도에 영향을 미친다는 결 과를 보여주었으며. 손준상(2009)의 연구에서 감 정정보는 감정적 태도를 통해서 행동에 영향을 미친다고 한다. Foxall, Yani-de-Soriano(2005) 는 소비자들의 감정반응을 중요한 영향요인으 로 제시하며, 즐거움, 환기. 지배가 접근-회피행 동에 유의한 영향을 미친다는 사실을 검증하였 다. 따라서 제품에 대한 소비자의 감정반응은 소비자의 구매의도에도 영향을 미친다고 보고, 본 연구에서는 구매의도를 소비자가 아트제품 을 구매하고자 하는 의도로 보고, 본 연구의 결 과변수로 연구하고자 한다.

김한구, 정보희. 주우진(2011)의 연구에서 명 화를 차용한 제품이 소비자의 감정에 미치는 영향을 살펴보았는데. 본 연구에서는 아트 콜라 보레이션 제품에 대해 소비자의 개인특성이 감 정에 미치는 영향과 감정이 아트 콜라보레이션 제품 구매의도에 미치는 영향을 살펴보고자 한다.

\section{5 성별에 따른 조절효과}

성별은 마케팅 연구의 기본적 시장 세분화 요 인으로 남녀 간의 차이는 대상물에 대한 태도 와 행동을 예측할 수 있는 변수로 이용되고 있 다. Meyer-Levy(1989)의 선택적 가설이론으로 남녀의 인지적인 정보처리의 차이를 설명할 수 있으며. 남녀 간의 행동에는 분명한 차이가 있 다. 남성은 정보처리에 있어 자신의 목표와 부 합되는 정보만을 선택적으로 받아들이며 특정 정보만을 이용하여 처리하는 반해, 여성은 가능 한 모든 정보를 고려하여 각 정보들의 연결성 을 고려하여 처리한다. 그리고 남성은 지배욕구 를 달성하기 위해 공격적인 언어 사용을 하기 쉬우나, 여성은 섬세하고 민감한 단어를 사용한 다(Brizendine, 2007). 또한 남성은 문제나 걱정 을 내면화하는 경향이 있는 반면에, 여성은 자 신의 문제나 걱정을 다른 여성과 공유하려 한다. 그리고 여성은 시각적 기억을 더 잘하며, 사건 과 물체의 위치를 더 잘 기억한다(Cramphorn. 2011). 청각, 후각, 미각, 시각. 촉각에 이르기까 지 성별에 차이가 있으며. 여성이 남성보다 더 민감하다는 것을 알 수 있다(Moir and Jessel. 1991).

정혜경(1998)의 연구에서 남녀는 아동시기부 터 선호도가 다르며. 성인의 경우 브랜드에 의 해 후광효과가 일어난다고 보았으며. Heslop. Wall(1985)의 연구에서 고품격 패션제품에 대 해서는 여성이 남성보다 더 호의적인 것으로 나타났다. 따라서 아트를 이용하여 제품의 가치 를 높이는 후광효과를 일으키며. 이에 반응하는 남녀의 반응은 다를 것이라고 본다. 그리고 선 물구입 상황에서 여성이 남성보다 독특성. 유행 
하는 속성, 재미있는 속성을 더 중요하게 지각 한다(김은영, 김윤경, 김연숙. 2002). 따라서 여 성이 남성에 비해 고품격 패션이나 브랜드 후 광효과에 민감하게 반응한다는 것을 알 수 있 다. 제품의 가치를 높이고자 하는 아트 콜라보 레이션 제품의 경우, 호기심과 소비자의 감정. 독특성 추구성향과 소비자의 감정 사이의 관계 에서 여성이 남성보다 더 호의적으로 받아들일 것으로 예측할 수 있다.

\section{III. 연구모형}

\section{1 연구모형}

본 연구는 개인특성인 호기심과 독특성 추구 성향이 아트 콜라보레이션 제품에 대한 소비자 의 감정에 미치는 영향과 소비자의 감정 반응 이 아트제품의 구매의도에 미치는 영향을 검증 하고자 한다. 호기심은 탐색적 행동 동기가 되 는 새로운 감각적 경험과 새로운 정보나 지식
을 획득하기 위한 욕구이며, 변화하는 환경에 유연하게 적응하도록 도와주는 역할을 한다 (Voss, Keller, 1983). 독특성 추구성향은 스스 로가 남들과 유사하다고 느끼게 될 때 다르게 보이고 싶은 성향을 뜻하며, Tian et al.(2001) 의 연구를 바탕으로 창의적 선택. 비대중적 선 택, 유사성 회피의 세 차원으로 구분한다. 창의 적 선택은 자신의 정체성 표현을 위해 자신만 의 스타일을 고안하고자 하는 성향을 말하며. 비대중적 선택은 집단의 규칙을 벗어나 자신을 차별화하려는 성향을 말하며, 유사성 회피는 제 품이나 브랜드가 유행을 하게 되어 대중화되면 흥미와 관심이 떨어지는 개인의 성향을 말한다.

아트 콜라보레이션 제품은 독창적이고 희소성 이 강한 제품으로 개인의 호기심을 자극하고, 잠재된 독특성 욕구를 자극할 수 있다고 보고, 여러 개인 특성 중 호기심과 독특성 추구성향 에 따라 아트 콜라보레이션 제품에 대한 소비 자의 감정과 구매의도가 달라질 것으로 예측하 고 연구하고자 한다. 본 연구모형은 〈그림 3-1〉 과 같다.

〈그림 3-1〉 연구모형

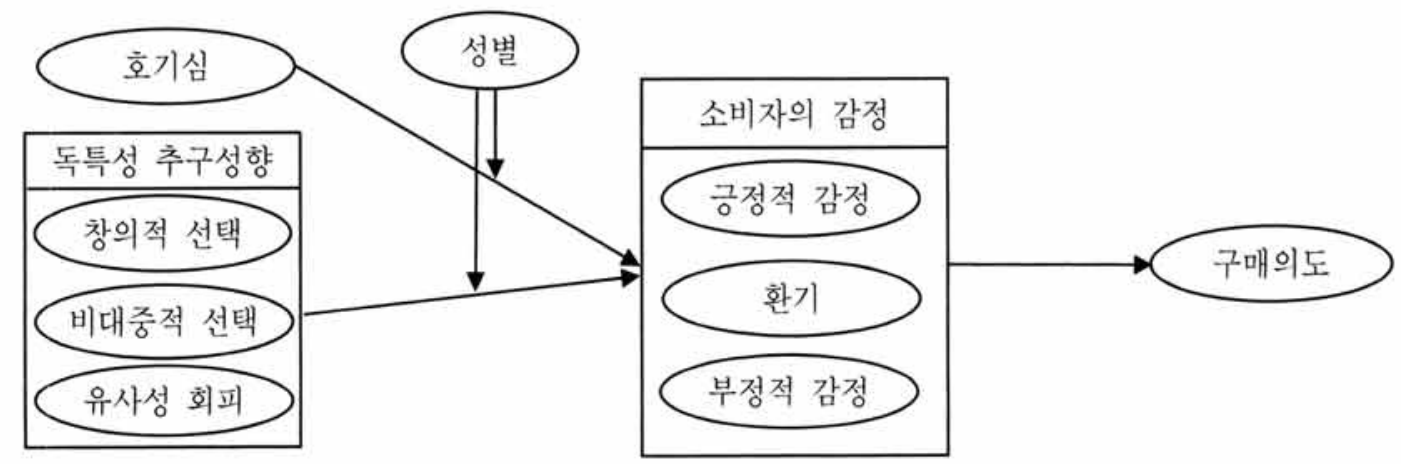




\section{2 연구가설}

\section{2 .1 호기심이 아트제품에 대한 소비자의 감정반응에 미치는 영향}

호기심은 개인이 새롭거나 복잡한 또는 애매 모호한 자극이나 환경을 접할 때 나타나는 개 인특성으로 개인이 어떠한 자극으로 인해 호기 심을 느끼면 오감을 통해 자극을 받아들이게 된다. 오감을 통해 자극을 받아들임으로서 주변 상황을 판단하고 지각한다(Stell, Paden, 1999). 또한 호기심을 통해 변화하는 환경에 보다 유연 하게 적응할 수 있게 된다(Voss, Keller, 1983). Litman, Spielberger(2003)의 연구에서 호기심 은 탐색적 행동 동기가 되며. 새로운 감각적 경 험과 새로운 정보나 지식을 획득하고자 하는 욕구로 정의한다.

따라서 호기심을 느끼는 정도에 따라 아트 콜 라보레이션 제품에 대해 지각하는 정도가 달라 질 것으로 본다. 호기심을 많이 느끼는 사람은 정보를 획득하는 상황을 즐겁게 받아들이며. 제 품에 대해서도 긍정적 감정을 가질 수 있다. 그 러나 호기심이 적은 사람은 새로운 제품에 대 해서 관심을 별로 보이지 않으며 알고 싶어하 지도 않기 때문에 긍정적이지 않을 수 있다. 아 트 콜라보레이션 제품은 아트를 접목한 새로운 시도로 호기심을 자극할 수 있는 제품이며. 이 를 마케팅에 이용했을 때도 소비자의 호기심을 자극할 수 있다고 본다. 따라서 본 연구에서는 호기심이 아트 콜라보레이션 제품에 대한 감정 에 영향을 미칠 것으로 보고 연구하고자 한다.

가설 1: 호기심은 아트 콜라보레이션 제품에
대한 소비자의 감정반응에 영향을 미 친다.

가설 1-1: 호기심은 아트제품에 대한 소비 자의 긍정적 감정에 정의 영향 을 미친다.

가설 1-2: 호기심은 아트제품에 대한 소비 자의 환기에 정의 영항을 미친다.

가설 1-3: 호기심은 아트제품에 대한 소비 자의 부정적 감정에 부의 영향 을 미친다.

\section{2 .2 독특성 추구성향이 아트제품에 대한 소비자의 감정반응에 미치는 영향}

사람들은 본질적으로 자신을 표현하고자 하는 욕구가 잠재되어 있다(Snyder, Fromkin, 1977). Tian et al,(2001)의 연구를 바탕으로 독특성 추구성향을 세 가지 차원으로 구분할 수 있는 데, 첫째. 창의적 선택성향은 자신의 정체성 표 현을 위해 소비재를 통해 자신만의 스타일을 만들고자 하는 성향이며. 둘째, 비대중적 선택 성향은 집단의 규칙. 질서를 벗어나 자신만의 스타일을 만들고자하는 성향이다. 셋째, 유사성 회피성향은 대중에게 알려진 제품에 대해서는 흥미를 잃어 사용을 꺼려하게 되는 성향을 말 한다. Lynn, Harris(1997)에 의하면 독특성 추 구성향은 개인의 성향으로. 독특성 추구성향이 높으면 다른 사람에 비해 먼저 새로운 제품을 선택하려는 성향이 크다고 한다. 즉. 다른 사람 들과 다르게 보이고 싶은 욕구로 인해 다양한 방법으로 자신을 표현하는데. 이를 독특성 추구 성향이라 한다. 독특성 표현의 정도가 높으면 자신만의 스타일을 연출하기 위해 남들과는 다 
른 것을 추구한다. 희소하며 창의적인 아트제품 의 특성으로 인해 아트제품을 이용하면 자신의 정체성을 쉽게 표현할 수 있으므로 긍정적 감 정을 가지며, 아트제품에 환기가 쉽게 일어난다 고 본다. 그러나 아트제품에 대해서 부정적 감 정에는 부의 영향을 미칠 것으로 보고 다음과 같은 가설을 제시한다.

가설 2: 독특성 추구성향은 아트 콜라보레이 션 제품에 대한 소비자의 감정반응에 영향을 미친다.

가설 2-1: 창의적 선택성향은 아트제품에 대 한 소비자의 긍정적 감정에 정 의 영향을 미친다.

가설 2-2: 창의적 선택성향은 아트제품에 대 한 소비자의 환기에 정의 영향 을 미친다.

가설 2-3: 창의적 선택성향은 아트제품에 대 한 소비자의 부정적 감정에 부의 영향을 미친다.

가설 2-4: 비대중적 선택성향은 아트제품에 대한 소비자의 긍정적 감정에 정 의 영향을 미친다.

가설 2-5: 비대중적 선택성향은 아트제품에 대한 소비자의 환기에 정의 영 향을 미친다.

가설 2-6: 비대중적 선택성향은 아트제품에 대한 소비자의 부정적 감정에 부 의 영향을 미친다.

가설 2-7: 유사성 회피성향은 아트제품에 대 한 소비자의 긍정적 감정에 정의 영향을 미친다.

가설 2-8: 유사성 회피성향은 아트제품에 대
한 소비자의 환기에 정의 영향 을 미친다.

가설 2-9: 유사성 회피성향 아트제품에 대 한 소비자의 부정적 감정에 부 의 영향을 미친다.

\section{2 .3 소비자의 감정반응이 아트제품의 구매의도에 미치는 영향}

감정반응은 지각적. 심리적 느낌, 사고활동. 감정적 변화의 유발. 인지적 상태를 나타낸다 (Mehrabian, Russell.1974), 소비자의 감정반응 은 Donovan, Rossiter(1982)의 연구에서 즐거움, 환기, 통제로 구분된다. 그러나 많은 선행연구 (Donovan, Rossiter, 1982: Eroglu, Machleit, Davis, 2003: Mummalaneni, 2005: Davis, Wang, Lindridge, 2008)에서 통제 차원은 연구에 따라 영향이 없다고 하며. 영향이 있다 하더라도 필 요성에 대한 의문이 제기되어 왔기 때문에 본 연구에서는 통제 차원을 제외하고 긍정적 감정. 환기. 부정적 감정으로 구분한다. 구매의도는 개인의 계획된 미래의 구매행동을 하려는 의도 를 뜻하는 것으로 본 연구에서는 아트 콜라보 레이션 제품에 대한 소비자의 감정반응이 아트 콜라보레이션 제품 구매의도에 미치는 영향에 대 해 알아보고자 하며, 다음의 가설을 제시한다.

가설 3: 소비자의 긍정적 감정은 아트 콜라보 레이션 제품 구매의도에 정의 영향 을 미친다.

가설 4: 소비자의 환기는 아트 콜라보레이션 제 품 구매의도에 정의 영향을 미친다.

가설 5: 소비자의 부정적 감정은 아트 콜라 
보레이션 제품 구매의도에 부의 영 향을 미친다.

\section{2 .4 개인특성과 소비자의 감정 간의 성별에 따른 조절 효과}

남녀는 근본적으로 차이가 있으며. 아동시기 부터 선호도가 다르다(정혜경, 1998). 여성은 남 성에 비해 시각적 기억을 더 잘하며, 특이한 사건 이나 물체의 위치를 더 잘 기억한다(Cramphorn. 2011). 여성이 남성보다 오감에 더 민감하다(Moir, Jessel. 1991). 일반여성은 남성에 비해 브랜드 에 의해 후광효과가 크게 나타난다고 한다(정 혜경, 1998). 따라서 아트를 이용한 콜라보레이 션 제품 역시 가치를 높이는 전략으로 후광효 과를 일으킬 수 있으며. 남성에 비해 여성이 후 광효과가 쉽게 일어난다고 본다. Heslop. Wall (1985)의 연구에서 고품격 패션제품에 대해서 는 여성이 남성보다 더 호의적이며, 김은영 외 (2002)의 연구는 선물을 구매할 때 여성이 남 성보다 독특성. 유행하는 속성, 재미있는 속성 을 더 중요하게 지각한다고 밝힌다. 아트 콜라 보레이션 제품의 경우. 고품격 패션제품에 속하 며 독특성과 재미있는 속성을 갖추고 있는 제 품이므로 여성과 남성이 받아들이는 정도를 다 를 수 있다고 본다.

초기 콜라보레이션은 패션제품에서 시작되었 는데. 여성의 옷이나 가방 제품에 아트를 활용 하였다. 여성용 제품에 아트를 활용했다는 것은 그만큼 여성이 아트에 대한 관심도가 높으며. 아트에 더 크게 반응한다는 것을 뜻한다. 현재 는 아트 활용범위가 점차 넓어져 남성제품과 가전제품, 생활필수품에까지 다양해지고 있지
만. 일반적으로 여성은 남성보다 감수성이 풍부 하며. 심미성에 관심이 높기 때문에 여성은 남 성보다 아트에 대해 더 민감하게 반응할 것으 로 예측할 수 있다. 따라서 호기심. 독특성 추 구성향과 아트제품에 대한 소비자의 감정 사이 에 성별의 차이가 있으며. 여성의 호기심 및 독 특성 추구성향이 남성의 호기심 및 독특성 추 구성향에 비해 아트 콜라보레이션 제품에 대해 긍정적 감정을 가지고, 환기가 더 쉽게 일어나 며. 부정적 감정은 남성이 여성보다 더 쉽게 일 어날 것으로 보았다. 성별에 따라 호기심 및 독 특성 추구성향과 소비자의 감정 사이에 영향력 을 달라질 것으로 보고 다음의 가설을 제시한다.

가설 6: 성별에 따라 개인특성과 아트 콜라 보레이션 제품에 대한 소비자의 감 정 사이에 미치는 영향은 차이가 있 을 것이다.

가설 6-1: 여성의 호기심은 남성의 호기심 에 비해 아트제품에 대한 긍정 적 감정에 미치는 영향이 더 클 것이다.

가설 6-2: 여성의 호기심은 남성의 호기심 에 비해 아트제품에 대한 환기 에 미치는 영향이 더 클 것이다.

가설 6-3: 남성의 호기심은 여성의 호기심 에 비해 아트제품에 대한 부정 적 감정에 미치는 영향이 더 클 것이다.

가설 6-4: 여성의 창의적 선택성향은 남성 의 창의적 선택 성향에 비해 아 트제품에 대한 긍정적 감정에 미 치는 영향이 더 클 것이다. 
가설 6-5: 여성의 창의적 선택성향은 남성 의 창의적 선택 성향에 비해 아 트제품에 대한 환기에 미치는 영향이 더 클 것이다.

가설 6-6: 남성의 창의적 선택성향은 여성 의 창의적 선택 성향에 비해 아 트제품에 대한 부정적 감정에 미치는 영향이 더 클 것이다.

가설 6-7: 여성의 비대중적 선택성향은 여 성의 비대중적 선택 성향에 비해 아트제품에 대한 긍정적 감정에 미치는 영향이 더 클 것이다.

가설 6-8: 여성의 비대중적 선택성향은 남 성의 비대중적 선택성향에 비해 아트제품에 대한 환기에 미치는 영향이 더 클 것이다.

가설 6-9: 남성의 비대중적 선택성향은 여 성의 비대중적 선택성향에 비해 아트제품에 대한 부정적 감정에 미치는 영향이 더 클 것이다.

가설 6-10: 여성의 유사성 회피성향은 남 성의 유사성 회피성향에 비해 아트제품에 대한 긍정적 감정에
미치는 영향이 더 클 것이다.

가설 6-11: 여성의 유사성 회피성향은 남 성의 유사성 회피성향에 비해 아트제품에 대한 환기에 미치 는 영향이 더 클 것이다.

가설 6-12: 남성의 유사성 회피성향은 남 성의 유사성 회피성향에 비해 아트제품에 대한 부정적 감정에 미치는 영향이 더 클 것이다.

\section{IV. 연구방법 및 분석결과}

\section{1 설문지 구성}

본 연구의 설문지 각 개념의 출처는 연구가설 을 제시하는데 이론적 근거가 되었던 선행연구 를 참고하였으며, 선행연구는 다음 〈표 4-1〉와 같다. 본 연구에서 사용된 각 개념의 측정항목 들은 선행연구에서 신뢰성이 확보된 척도를 기 반으로 사용하였으며. 본 연구에 적합하도록 약 간의 수정을 거쳐 7점 리커트 척도로 측정할

〈표 4-1〉 설문지 구성

\begin{tabular}{|c|c|c|c|c|}
\hline \multicolumn{3}{|c|}{ 개 념 } & 측정항목 & 출 처 \\
\hline \multirow{4}{*}{ 개인특성 } & \multicolumn{2}{|c|}{ 호기심 } & 10 & Stell. Paden(1999) \\
\hline & \multirow{3}{*}{$\begin{array}{l}\text { 독특성 } \\
\text { 추구성향 }\end{array}$} & 창의적 선택 & 5 & \multirow{3}{*}{ Tian. Bearden. Hunter (2001) } \\
\hline & & 비대중적 선택 & 3 & \\
\hline & & 유사성 회피 & 5 & \\
\hline \multirow{3}{*}{$\begin{array}{l}\text { 소비자의 } \\
\text { 감정 반응 }\end{array}$} & \multicolumn{2}{|c|}{ 긍정적 감정 } & 3 & \multirow{3}{*}{$\begin{array}{c}\text { Donovan, Rossiter(1982) } \\
\text { Watson. Clark. Tellegen(1988) }\end{array}$} \\
\hline & & 기 & 4 & \\
\hline & \multicolumn{2}{|c|}{ 부정적 감정 } & 3 & \\
\hline \multicolumn{3}{|c|}{ 구매의도 } & 3 & Davis(1989). Fishbein, Ajzen(1975) \\
\hline
\end{tabular}


수 있도록 설계되었다. 각 요인에서 사용된 구 체적인 측정항목은 〈표 4-2〉에서 확인해 볼 수 있다.

\section{2 자료수집 및 조사방법}

본 논문의 자료 수집은 주로 20 30대를 대상 으로 2011년 6월 29일에서 7월12일까지 설문조 사를 실시하였다. 설문기간 동안 총 350 부의 설 문지를 배포하여 미완성된 설문을 제거하고 300
부(유효 응답율 $85.7 \%$ )를 회수하였다.

수집된 자료에 대한 분석은 SPSS 14.0과 LISREL 8.7을 이용하였다. 인구 통계적 특성과 개인 특성인 호기심과 독특성 추구성향, 소비자 의 감정반응. 구매의도에 대한 타당성과 신뢰성 등 내적일관성 검증은 SPSS 14.0 을 이용하였으 며. 척도의 정제에 필요한 측정모델 검증과 가 설검정을 하는데 필요한 구조모델 검증은 LISREL 8.7 을 이용하였다.

〈표 4-2〉 인구통계적 특성

\begin{tabular}{|c|c|c|c|}
\hline \multicolumn{2}{|r|}{ 응답자 특성 } & 빈도(명) & 응답비율 $(\%)$ \\
\hline \multirow{2}{*}{ 성별 } & 남성 & 136 & 45.3 \\
\hline & 여성 & 164 & 54.7 \\
\hline \multirow{4}{*}{ 연령 } & 20세 - 29세 이하 & 233 & 77.7 \\
\hline & 30세 - 39세 이하 & 35 & 11.7 \\
\hline & 40세 - 49세 이하 & 17 & 5.7 \\
\hline & 50 세 이상 & 15 & 5.0 \\
\hline \multirow{4}{*}{ 교육수준 } & 고등학교 졸업 & 22 & 7.3 \\
\hline & 전문대학 재학/졸업 & 19 & 6.3 \\
\hline & 대학교 재학/졸업 & 242 & 80.7 \\
\hline & 대학원 재학/졸업 이상 & 17 & 5.7 \\
\hline \multirow{7}{*}{ 직업 } & 학생 & 211 & 70.3 \\
\hline & 회사원 & 21 & 7.0 \\
\hline & 공무원 & 32 & 10.7 \\
\hline & 자영업 & 7 & 2.3 \\
\hline & 전문직 & 9 & 3.0 \\
\hline & 주부 & 11 & 3.7 \\
\hline & 기타 & 9 & 3,0 \\
\hline \multirow{2}{*}{ 결혼여부 } & 미혼 & 251 & 83.7 \\
\hline & 기혼 & 49 & 16.3 \\
\hline \multirow{5}{*}{$\begin{array}{c}\text { 한 달 } \\
\text { 개인소득 }\end{array}$} & 100 만원미만 & 204 & 68.0 \\
\hline & 100 만원이상- 300 만원미만 & 67 & 22.3 \\
\hline & 300 만원이상 -500 만원미만 & 21 & 7.0 \\
\hline & 500 만원이상- 700 만원미만 & 3 & 1.0 \\
\hline & 700 만원이상 & 5 & 2.7 \\
\hline & 합 계 & 300 & 100 \\
\hline
\end{tabular}




\section{3 표본의 특성}

본 조사의 인구통계적 특성은 〈표 4-2〉에 잘 나타나 있다. 남성과 여성의 비율이 각각 $45.3 \%$, $54.7 \%$ 로 거의 비슷하며, 연령별 구성은 20 대가 233 명. $77.7 \%$ 로 대부분의 비율을 차지하는 것 으로 나타났다. 교육수준은 대학교 재학 및 졸 업이 $80.7 \%$ 로 과반수이상의 비율을 차지하였다. 직업별 구성분포를 보면 학생이 $70.3 \%$ 로 과반 수이상을 차지하였으며. 결혼여부에서도 미혼이 $83.7 \%$ 로 대부분을 차지하였다. 개인소득에서도 대부분이 용돈을 받거나 아르바이트를 하는 학 생으로 $68.0 \%$ 가 100 만원미만의 수입을 나타내 었다. 본 연구는 주로 20 대를 대상으로 하였다. 콜라보레이션은 고가의 제품에서 시작되었지만 최근에는 럭셔리 제품 외에도 생활필수품에 이 르기까지 다양한 제품에서 이루어지고 있다. 물 병, 여성용품, 화장품, 음료, 운동화 등 저가에 서 고가에 이르기까지 여러 분야의 제품에서 콜라보레이션이 이루어지고 있기 때문에 구매 력이 다소 약한 학생들도 아트 콜라보레이션 제품을 접할 수 있다. 그리고 다소 보수적일 수 있는 중년층보다 젊은층일수록 새로운 것을 쉽 게 받아들이는 성향이 높으며. 럭셔리 제품에서 도 20 대는 잠재적 고객이 될 수 있으므로 연구 의 표본대상으로 적절하다고 본다.

\section{4 확인요인분석}

연구모형의 가설을 검증하기 전에 모델에 투 입된 변수들의 특성을 살펴보기 위해 LISREL 8.7 을 이용하여 확인요인분석을 실시하였다.

〈표 4-3〉는 개인특성인 호기심과 독특성 추구
성향에 대한 확인요인분석의 결과를 나타낸다. 모든 변수의 크론바 알파값이 0.7 이상으로 나타 나 내적일관성이 있음을 보여준다. 그리고 모든 변수의 표준적재치의 기준값인 0.5 를 상회하는 것으로 나타났으며. 복합신뢰지수도 기준값 0.6 을 훨씬 상회하는 0.8 내외를 나타내고 있다. 또 한 분산추출값 역시 기준값 0.5 이상으로 수렴타 당성이 있음을 확인할 수 있다. 측정모델의 적 합도를 보면, 카이제곱값은 183.70 , 자유도 98 $(\mathrm{p}=0.00)$ 로 나타났다. GFI 값과 AGFI값은 0.929, 0.901 로 나타났으며 $\mathrm{NFI}$ 값과 $\mathrm{NNFI}$ 값은 각각 $0.973,0.983$ 로 나타나 권고기준을 상회한다. 따 라서 본 연구의 변수들은 내적일관성과 수렴타 당성이 있다고 본다.

〈표 4-4〉는 소비자의 감정과 구매의도에 대한 확인요인분석의 결과를 보여준다. 각 개념의 크 론바 알파값이 0.918 이상으로 나타났으며. 항목 대 개념평균값 상관계수는 0.794 이상으로 나타 나 내적일관성이 있음을 알 수 있다. 그리고 표 준적재치의 값이 0.8 을 상회하고 있으며. 복합 신뢰지수와 분산추출값이 권고기준값인 0.5 이상 으로 나타나 수렴타당성도 있다고 볼 수 있다. 적합도를 보면 카이스웨어 값이 122.33 , 자유도 $48(\mathrm{p}=0.00)$ 로 나타났으며. GFI과 AGFI의 값 이 각각 $0.936,0.896$ 으로 나타나 권고기준을 상 회하여 측정모델로 적합함을 보여준다.

\section{5 판별타당성 분석}

판별타당성 검증을 위해 상관분석을 실시하여 분산추출값과 비교하였다. 판별타당성 분석의 기준은 연구대상 개념 간 상관계수의 제곱이 분산추출값보다 작으면 판별타당성이 있다고 
〈표 4-3〉 호기심, 독특성 추구성향의 확인요인분석

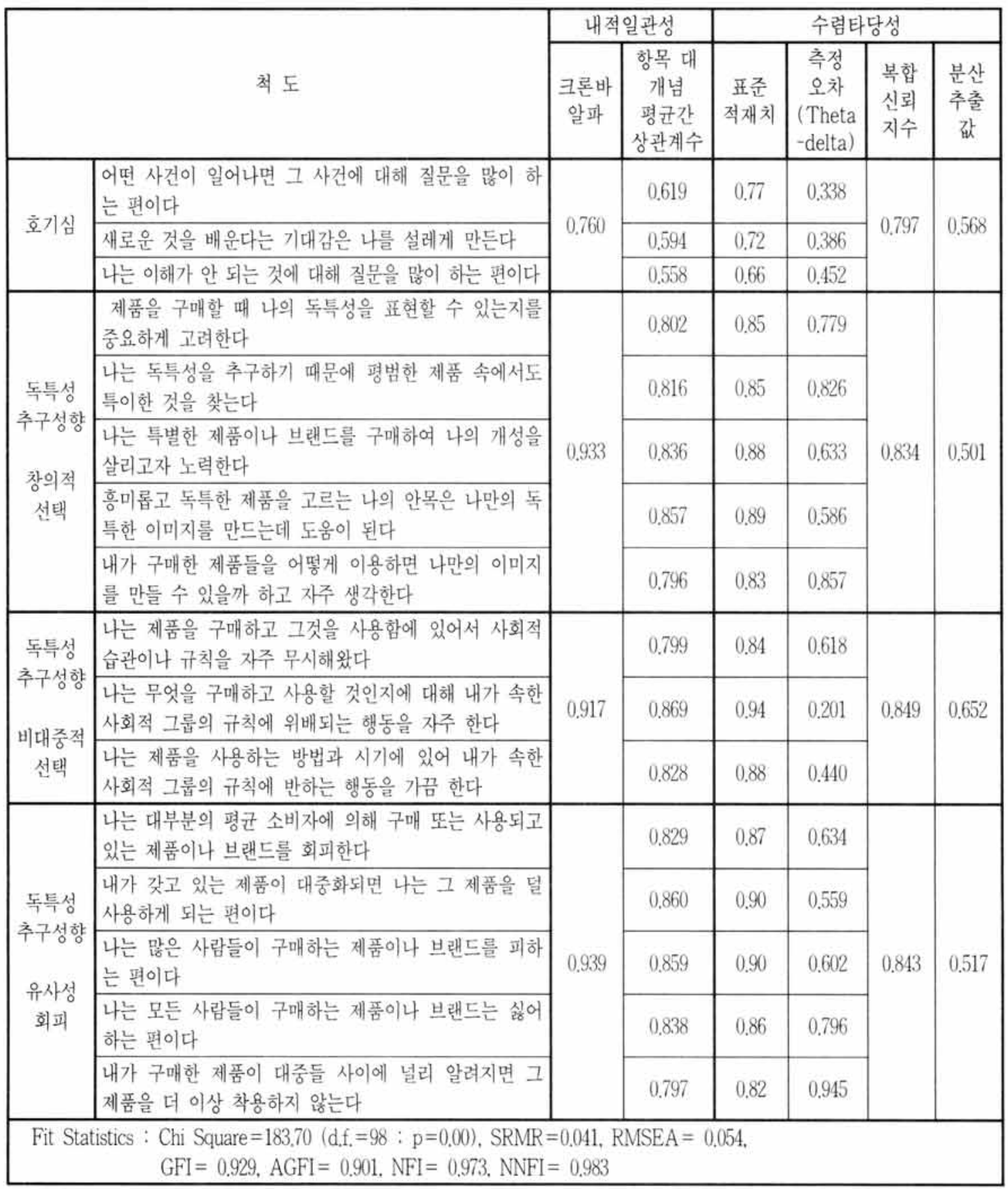

본다. 〈표 4-5〉는 본 연구의 판별타당성을 분석 값보다 작기 때문에 본 연구의 가설은 판별타 한 것으로. 모든 상관계수의 제곱이 분산 추출 당성이 있다고 본다. 
〈표 4-4〉 소비자의 감정, 구매의도의 확인요인분석

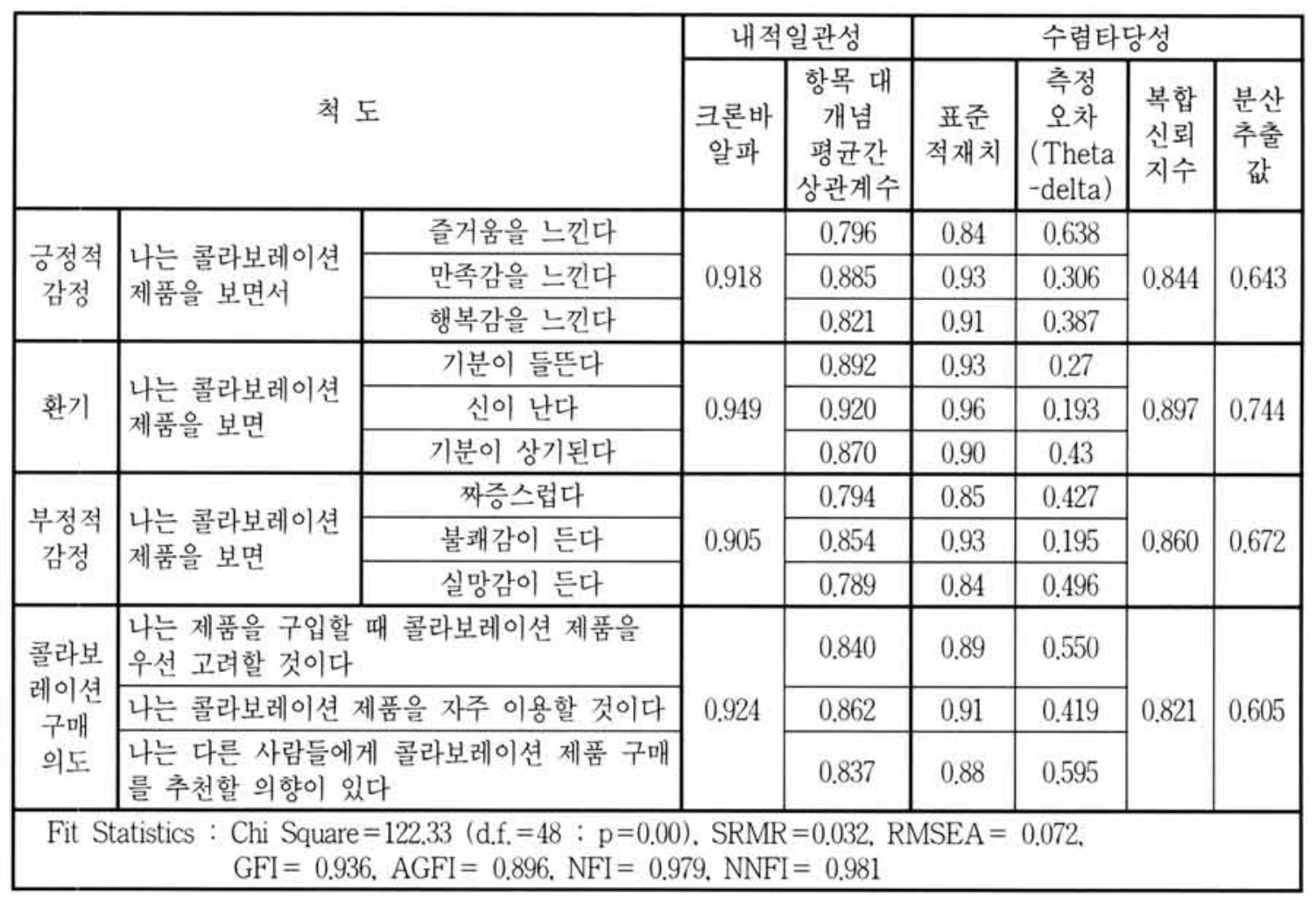

〈표 4-5〉 판별타당성 분석

\begin{tabular}{|c|c|c|c|c|c|c|c|c|}
\hline & 호기심 & $\begin{array}{l}\text { 독특 } \\
\text { 창의 }\end{array}$ & $\begin{array}{c}\text { 독특 } \\
\text { 비대중 }\end{array}$ & $\begin{array}{c}\text { 독특 } \\
\text { 유사회피 }\end{array}$ & 긍정 & 환기 & 부정 & 구매의도 \\
\hline 호기심 & .568 & & & & & & & \\
\hline $\begin{array}{l}\text { 독특 } \\
\text { 창의 }\end{array}$ & $\begin{array}{l}.087 \\
(.0076)\end{array}$ & .501 & & & & & & \\
\hline $\begin{array}{c}\text { 독특 } \\
\text { 비대중 }\end{array}$ & $\begin{array}{c}-.041 \\
(.0017)\end{array}$ & $\begin{array}{c}.288 \\
(.0829)\end{array}$ & .652 & & & & & \\
\hline $\begin{array}{c}\text { 독특 } \\
\text { 유사회피 }\end{array}$ & $\begin{array}{c}.010 \\
(.0001)\end{array}$ & $\begin{array}{c}.701 \\
(.4914) \\
\end{array}$ & $\begin{array}{c}.302 \\
(.0912)\end{array}$ & .517 & & & & \\
\hline 긍정 & $\begin{array}{c}.104 \\
(.0108) \\
\end{array}$ & $\begin{array}{c}.522 \\
(.2725) \\
\end{array}$ & $\begin{array}{c}.174 \\
(.0303) \\
\end{array}$ & $\begin{array}{c}.433 \\
(.1875) \\
\end{array}$ & .643 & & & \\
\hline 환기 & $\begin{array}{c}.087 \\
(.0076) \\
\end{array}$ & $\begin{array}{c}.506 \\
(.2560) \\
\end{array}$ & $\begin{array}{c}.304 \\
(.0924) \\
\end{array}$ & $\begin{array}{c}.425 \\
(.1806) \\
\end{array}$ & $\begin{array}{c}.779 \\
(.6068) \\
\end{array}$ & .744 & & \\
\hline 부정 & $\begin{array}{c}-.057 \\
(.0032)\end{array}$ & $\begin{array}{c}-.161 \\
(.0259)\end{array}$ & $\begin{array}{c}.119 \\
(.0142)\end{array}$ & $\begin{array}{c}-.073 \\
(.0053)\end{array}$ & $\begin{array}{c}-.288 \\
(.0829) \\
\end{array}$ & $\begin{array}{c}-.182 \\
(.0331)\end{array}$ & .672 & \\
\hline 구매의도 & $\begin{array}{c}.089 \\
(.0079) \\
\end{array}$ & $\begin{array}{c}.532 \\
(.2830) \\
\end{array}$ & $\begin{array}{c}.306 \\
(.0936) \\
\end{array}$ & $\begin{array}{l}.455 \\
(.2070) \\
\end{array}$ & $\begin{array}{c}.712 \\
(.5069)\end{array}$ & $\begin{array}{l}.701 \\
(.4914)\end{array}$ & $\begin{array}{c}-.240 \\
(.0576)\end{array}$ & .605 \\
\hline
\end{tabular}

* 대각선의 계수는 분산추출값, 표 안의 값은 상관계수. 괄호 안의 값은 상관계수의 제곱임. 


\section{6 가설검증}

가설 검증을 위해 LISREL 8.7 프로그램을 이 용한 구조방정식모델을 이용하였다. 구조방정식 모델은 개인특성이 소비자의 감정에 미치는 영 향과 소비자의 감정이 아트제품 구매의도에 미 치는 영향에 대한 인과관계를 살펴보는데 적절 한 연구방법이다. 다음의 〈그림 4-1〉과 〈표 4-6〉 은 구조방정식모델을 이용하여 연구모형의 가 설검증 결과를 보여준다.

검증결과의 구조모델 적합도를 보면, 카이제 곱값은 707.97 이며. 자유도는 $329(\mathrm{p}=0.00)$ 이며, $\mathrm{GFI}=0.855, \mathrm{AGFI}=0.821 . \mathrm{NFI}=0.956 . \mathrm{NNFI}=$ 0.970 로 모두 권고기준인 0.8 을 상회하여 데이 터와 연구모형과 부합하고 있음을 보여준다.

가설1-1(호기심 $\rightarrow$ 긍정적 감정)은 표준경로 계수 $0.14, \mathrm{t}$ 값이 1.85 로 나타났다. $\mathrm{t}$ 값이 앙측검 증일 경우 1.96 이상이어야 채택이지만, 단측 검 증이므로 1.64 이상이면 채택되기 때문에 가설 1-1은 채택되었으며. 개인특성인 호기심이 아트 제품을 이용에 대한 소비자의 긍정적 감정에 정의 영향을 미치는 것으로 나타났다. 가설1-2
(호기심 $\rightarrow$ 환기)은 표준경로계수 $0.06, \mathrm{t}$ 값이 1.10 으로 가설이 기각되었다. 호기심은 아트제 품에 대해 소비자의 환기를 일으키는데 영향을 미치지 않는 것으로 나타났다. 가설1-3(호기심 $\rightarrow$ 부정적 감정)은 표준경로계수 $-0.05, \mathrm{t}$ 값이 -0.71 로 나타나 기각되었다. 개인특성인 호기심 은 아트제품에 대해 소비자의 부정적 감정이 부의 영향을 미치는 것으로 가설을 세웠으나 호기심과 부정적 감정 간에는 영향관계가 없는 것으로 나타났다.

가설2-1(독특성 추구성향 중 창의적 선택 $\rightarrow$ 긍정적 감정)은 표준경로계수 0.54 , t값 6.08 로 가설이 채택되었다. 독특성 추구성향 중 창의적 선택은 아트제품에 대한 소비자의 긍정적 감정 에 정의 영항을 미치는 것을 알 수 있다. 가설 2-2(독특성 추구성향 중 창의적 선택 $\rightarrow$ 환기) 은 표준경로계수 0.45 , t값 5.24로 나타나 채택 되었다. 자신의 정체성을 표현하고자 하는 개인 특성이 높은 사람은 아트제품에 대해 환기를 일으키는데 긍정적인 영향을 미친다는 결과를 보여준다. 가설2-3(독특성 추구성향 중 창의적 선택 $\rightarrow$ 부정적 감정)은 표준경로계수 $-0.34, \mathrm{t}$

〈그림 4-1〉 연구모형의 가설검증 결과

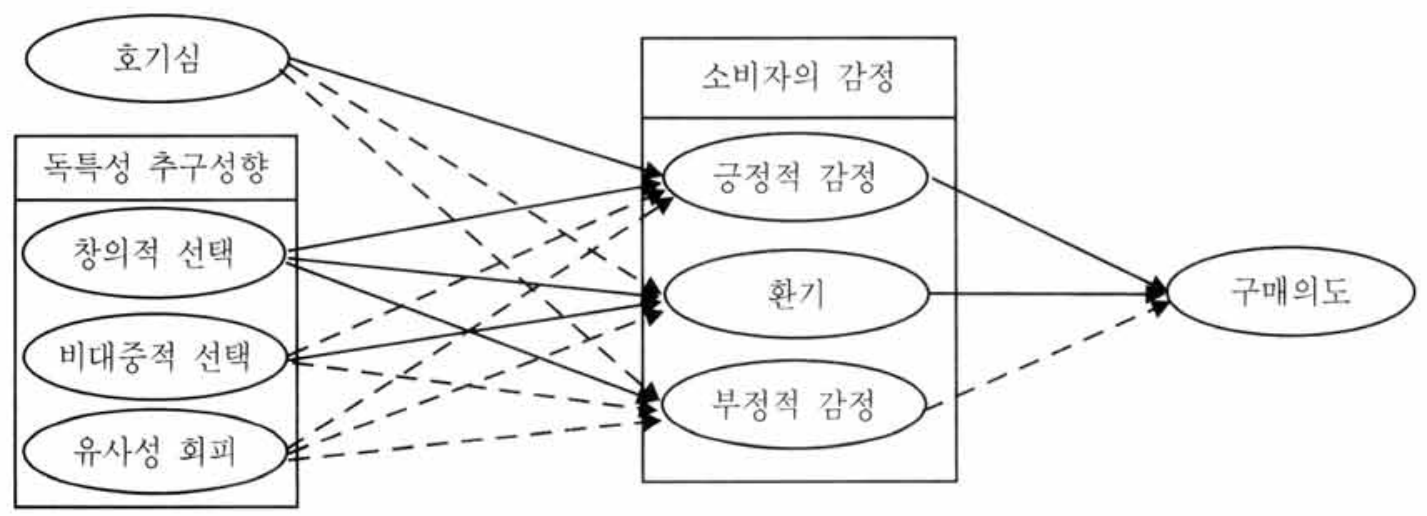


〈표 4-6〉가설검증결과

\begin{tabular}{|c|c|c|c|c|}
\hline 가설 & 경로 & $\begin{array}{l}\text { 경로계수 } \\
\text { (t값) }\end{array}$ & 표준경로계수 & 가설검증여부 \\
\hline 가설 1-1 & 호기심 $\rightarrow$ 긍정적 감정 & $\begin{array}{c}0.15 \\
(1.85)\end{array}$ & 0.14 & 0 \\
\hline 가설 1-2 & 호기심 $\rightarrow$ 환기 & $\begin{array}{c}0.12 \\
(1.10)\end{array}$ & 0.06 & $x$ \\
\hline 가설 1-3 & 호기심 $\rightarrow$ 부정적 감정 & $\begin{array}{c}-0.07 \\
(-0.71)\end{array}$ & -0.05 & $x$ \\
\hline 가설 2-1 & 창의적 선택 $\rightarrow$ 긍정적 감정 & $\begin{array}{c}0.46 \\
(6.08)\end{array}$ & 0.54 & 0 \\
\hline 가설 2-2 & 창의적 선택 $\rightarrow$ 환기 & $\begin{array}{c}0.42 \\
(5.24)\end{array}$ & 0.45 & 0 \\
\hline 가설 2-3 & 창의적 선택 $\rightarrow$ 부정적 감정 & $\begin{array}{c}-0.24 \\
(-3.36)\end{array}$ & -0.34 & 0 \\
\hline 가설 2-4 & 비대중적 선택 $\rightarrow$ 긍정적 감정 & $\begin{array}{c}0.03 \\
(0.49)\end{array}$ & 0.03 & $x$ \\
\hline 가설 2-5 & 비대중적 선택 $\rightarrow$ 환기 & $\begin{array}{c}0.22 \\
(3.48)\end{array}$ & 0.19 & 0 \\
\hline 가설 2-6 & 비대중적 선택 $\rightarrow$ 부정적 감정 & $\begin{array}{c}0.20 \\
(3.51)\end{array}$ & 0.23 & $x$ \\
\hline 가설 2-7 & 유사성 회피 $\rightarrow$ 긍정적 감정 & $\begin{array}{c}0.03 \\
(0.42)\end{array}$ & 0.04 & $x$ \\
\hline 가설 2-8 & 유사성 회피 $\rightarrow$ 환기 & $\begin{array}{c}0.04 \\
(0.48)\end{array}$ & 0,04 & $x$ \\
\hline 가설 2-9 & 유사성 회피 $\rightarrow$ 부정적 감정 & $\begin{array}{c}0.08 \\
(1.06)\end{array}$ & 0.10 & $x$ \\
\hline 가설 3 & 긍정적 감정 $\rightarrow$ 구매의도 & $\begin{array}{c}0.55 \\
(9.46)\end{array}$ & 0.50 & 0 \\
\hline 가설 4 & 환기 $\rightarrow$ 구매의도 & $\begin{array}{c}0.42 \\
(8.63)\end{array}$ & 0.42 & 0 \\
\hline 가설 5 & 부정적 감정 $\rightarrow$ 구매의도 & $\begin{array}{c}-0.06 \\
(-1.09)\end{array}$ & -0.05 & $x$ \\
\hline \multicolumn{5}{|c|}{$\begin{aligned} \text { Fit Statistics : } & \text { Chi Square }=707.97(\text { d.f. }=329: p=0.00) . \text { SRMR }= \\
& \text { GFI }=0.855, \text { AGFI }=0.821, \text { NFI }=0.956, \text { NNFI }=0.970\end{aligned}$} \\
\hline
\end{tabular}

값 -3.36 으로 나타나 정체성 표현 욕구가 강한 사람은 아트제품에 대해 부정적 감정을 느끼지 않는 것으로 나타났다.

가설2-4(독특성 추구성향 중 비대중적 선택 $\rightarrow$ 긍정적 감정)은 표준경로계수 0.03 , t값 0.49
로 나타나 가설이 기각되었다. 가설2-5(독특성 추구성향 중 비대중적 선택 $\rightarrow$ 환기)은 표준경 로계수 0.19, t값 3.48로 나타나 채택되었다. 가 설2-6(독특성 추구성향 중 비대중적 선택 $\rightarrow$ 부정적 감정)은 표준경로계수 0.23 , t값 3.51 로 
나타났다. 비대중적 선택이 강한 사람은 아트 제품에 대한 부정적 감정에 부의 영향을 미칠 것이라고 예측했으나 정의 영향을 미치는 것으 로 나타나 가설이 기각되었다. 즉. 집단의 규칙 에 얽매이기 싫어하는 성향이 높은 사람은 아 트제품에 부정적 감정을 느끼지 않을 것이라고 예측했지만, 그와는 반대로 아트제품에 대해 부 정적 감정을 느끼는 것을 알 수 있다.

가설2-7(독특성 추구성향 중 유사성 회피 $\rightarrow$ 긍정적 감정)은 표준경로계수 0.04 . t값 0.42 로 나타났으며, 가설2-8(독특성 추구성향 중 유사 성 회피 $\rightarrow$ 환기)은 표준경로계수 0.04 . t 값 0.48 으로 나타났고, 가설2-9(독특성 추구성향 중 유 사성 회피 $\rightarrow$ 부정적 감정)은 표준경로계수 0.10 , t값 0.10 로 나타나 세 가설이 모두 기각되었다. 유사성 회피성향이 강한 사람은 아트제품에 대 해 긍정적 감정과 환기를 유발할 것이라고 예 측했지만 아무런 영향이 없는 것으로 나타났으 며. 부정적 감정에는 부의 영향을 미칠 것이라 예 상했으나. 역시 영향이 없는 것으로 나타났다.

가설 3 (긍정적 감정 $\rightarrow$ 구매의도)는 표준경로 계수 0.50. $\mathrm{t}$ 값 9.46로 나타나 가설이 채택되었 다. 아트제품에 대한 소비자의 긍정적 감정은 아트제품 구매의도에 긍정적인 영항을 미치는 것을 알 수 있다. 가설 4 (환기 $\rightarrow$ 구매의도)는 표준경로계수 0.42 , t값 8.63 으로 나타나 가설이 채택되었다. 아트제품에 의한 소비자의 환기는 아트제품 구매의도에 긍정적인 영향을 미치는 것으로 나타났다. 가설 5 (부정적 감정 $\rightarrow$ 구매 의도)는 표준경로계수 $-0.05, t$ 값 -1.09 로 나타 나 가설이 기각되었다. 아트제품에 대한 소비자 의 부정적 감정은 아트제품 구매의도에 부의 영항을 미칠 것으로 예측하였으나. 부정적 감정
과 구매의도 간에는 영향이 미치는 않는 것으 로 나타났다.

\section{7 성별의 조절효과 검증}

성별에 따라 개인특성인 호기심과 독특성 추 구성향이 소비자의 감정에 미치는 영향은 달라 질 것으로 보고, 성별에 따른 조절효과를 검증 하였다. 남녀 두 집단으로 나누어 리즈렐을 이 용한 구조방정식을 통해 카이제곱 차이분석의 통계적 유의성으로 가설을 검증하였다. 집단 간 차이분석의 경우, 유의수준 $a=0.05$ 일 때, 1 자유 도 $\Delta \chi^{2}=3.841$ 이상이 되면 조절효과가 있다고 본다. 집단의 표본수는 남자 136 명이고, 여자 164 명이다. 제약을 가하지 않은 경우. 카이제곱 의 값이 1147.95 , d.f. $=658$ 로 나타났다. 〈표 4-7〉 에서 성별의 조절효과 검증결과를 보여준다.

가설6-1(호기심 $\rightarrow$ 긍정적 감정)은 $\Delta \chi^{2}=$ 2.98 로 나타나 어느 정도 카이제곱 차가 있지만 3.841 에 미치지 못하여 조절적 영향이 없는 것 으로 나타났다. 가설6-2(호기심 $\rightarrow$ 환기)는 $\triangle$ $\chi^{2}=2.48$ 로 나타났으며. 가설6-3(호기심 $\rightarrow$ 부 정적 감정 $)$ 도 $\Delta \chi^{2}=2.09$ 로 유의한 차이가 없 어 세 가설 모두 조절효과가 없음을 알 수 있 다. 성별에 따라 호기심과 감정 사이의 차이가 어느 정도 나타나기는 하지만 유의한 차이는 없는 것으로 보아. 아트 제품에 대한 호기심은 남녀의 차이가 아니며. 개인의 성향에 따른 것 으로 볼 수 있다.

가설6-4(창의적 선택 $\rightarrow$ 긍정적 감정)은 $\Delta \chi^{2}$ $=1.55$ 로 나타났으며. 가설 $6-5$ (창의적 선택 $\rightarrow$ 환기) 은 $\Delta \chi^{2}=0$ 으로 나타나 두 가설은 카이제 곱 차이가 없으므로 조절효과가 없음을 알 수 
〈표 4-7〉성별에 따른 조절효과

\begin{tabular}{|c|c|c|c|c|c|}
\hline & \multicolumn{5}{|c|}{ 가설 6} \\
\hline 조절변수 & \multicolumn{5}{|c|}{$N_{\text {urult }}=136, N_{\text {frumule }}=164$} \\
\hline 비제약모델 & \multicolumn{5}{|c|}{ d.f. $=658 . \chi^{2}=1147.95$} \\
\hline & 제약모델 & 집단구분 & $\begin{array}{l}\text { Standard } \\
\text { solution }\end{array}$ & $\mathrm{t}$ 값 & 채택여부 \\
\hline \multirow{2}{*}{ 가설6-1 } & \multirow{2}{*}{$\begin{array}{c}\text { 호기심 } \rightarrow \text { 긍정적 감정 } \\
\chi^{2}=1150.93 \text { d.f. }=659 \\
\Delta \chi^{2}=2.98\end{array}$} & 남 & -0.09 & -0.93 & \multirow{2}{*}{$x$} \\
\hline & & 여 & 0.18 & 2.56 & \\
\hline \multirow{2}{*}{ 가설6-2 } & \multirow{2}{*}{$\begin{array}{c}\text { 호기심 } \rightarrow \text { 환기 } \\
\chi^{2}=1150.43 \text { d.f. }=659 \\
\Delta \chi^{2}=2.48\end{array}$} & 남 & -0.08 & -0.98 & \multirow{2}{*}{$x$} \\
\hline & & 여 & 0.15 & 2.04 & \\
\hline \multirow{2}{*}{ 가설6-3 } & \multirow{2}{*}{$\begin{array}{c}\text { 호기심 } \rightarrow \text { 부정적 감정 } \\
\chi^{2}=1150.04 \text { d.f. }=659 \\
\Delta \chi^{2}=2.09\end{array}$} & 남 & 0.12 & 1.18 & \multirow{2}{*}{$x$} \\
\hline & & 여 & -0.12 & -1.46 & \\
\hline \multirow{2}{*}{ 가설6-4 } & \multirow{2}{*}{$\begin{array}{c}\text { 창의적 선택 } \rightarrow \text { 긍정적 감정 } \\
\chi^{2}=1149.50 \text { d.f. }=659 \\
\Delta \chi^{2}=1.55\end{array}$} & 남 & 0.82 & 5.88 & \multirow{2}{*}{$x$} \\
\hline & & 여 & 0.30 & 2.75 & \\
\hline \multirow{2}{*}{ 가설6-5 } & \multirow{2}{*}{$\begin{array}{c}\text { 창의적 선택 } \rightarrow \text { 환기 } \\
\chi^{2}=1147.95 \text { d.f. }=659 \\
\Delta \chi^{2}=0\end{array}$} & 남 & 0.58 & 4.77 & \multirow{2}{*}{$x$} \\
\hline & & 여 & 0.36 & 3.01 & \\
\hline \multirow{2}{*}{ 가설6-6 } & \multirow{2}{*}{$\begin{array}{c}\text { 창의적 선택 } \rightarrow \text { 부정적 감정 } \\
\chi^{2}=1152.13 \text { d.f. }=659 \\
\Delta \chi^{2}=4.18\end{array}$} & 남 & -0.53 & -3.62 & \multirow{2}{*}{0} \\
\hline & & 여 & -0.22 & -1.69 & \\
\hline \multirow{2}{*}{ 가설6-7 } & \multirow{2}{*}{$\begin{array}{c}\text { 비대중적 선택 } \rightarrow \text { 긍정적 감정 } \\
\chi^{2}=1144.53 \text { d.f. }=659 \\
\Delta \chi^{2}=3.42\end{array}$} & 남 & -0.09 & -1.03 & \multirow{2}{*}{$x$} \\
\hline & & 여 & 0.11 & 1.50 & \\
\hline \multirow{2}{*}{ 가설6-8 } & \multirow{2}{*}{$\begin{array}{l}\text { 비대중적 선택 } \rightarrow \text { 환기 } \\
\chi^{2}=1146.50 \text { d.f. }=659 \\
\Delta \chi^{2}=1.45\end{array}$} & 남 & 0.10 & 1.34 & \multirow{2}{*}{$\times$} \\
\hline & & 여 & 0.26 & 3.34 & \\
\hline \multirow{2}{*}{ 가설6-9 } & \multirow{2}{*}{$\begin{array}{c}\text { 비대중적 선택 } \rightarrow \text { 부정적 감정 } \\
\chi^{2}=1155.31 \quad \text { d.f. }=659 \\
\Delta \chi^{2}=7.36\end{array}$} & 남 & 0.44 & 4.42 & \multirow{2}{*}{0} \\
\hline & & 여 & 0.08 & 0.91 & \\
\hline \multirow{2}{*}{ 가설6-10 } & \multirow{2}{*}{$\begin{array}{c}\text { 유사성 회피 } \rightarrow \text { 긍정적 감정 } \\
\chi^{2}=1148.11 \text { d.f. }=659 \\
\Delta \chi^{2}=0.16\end{array}$} & 남 & -0.03 & -0.31 & \\
\hline & & 여 & 0.10 & 0.84 & $x$ \\
\hline - & 유사성 회피 $\rightarrow$ 환기 & 남 & 0.07 & 0.70 & \\
\hline 가설6- 11 & $\begin{array}{c}\chi^{2}=1148.17 \text { d.f. }=659 \\
\Delta \chi^{2}=0.22\end{array}$ & 여 & -0.03 & -0.25 & $x$ \\
\hline & 유사성 회피 $\rightarrow$ 부정적 감정 & 남 & 0.17 & 1.38 & \\
\hline 6-12 & $\begin{array}{c}\chi^{2}=1148.12 \text { d.f. }=659 \\
\Delta \chi^{2}=0.17\end{array}$ & 여 & 0.08 & 0.50 & $x$ \\
\hline
\end{tabular}


있다. 가설6-6(창의적 선택 $\rightarrow$ 부정적 감정)은 $\Delta \chi^{2}=4.18$ 로 나타나 조절효과가 있는 것으로 나타났다. $\mathrm{t}$ 값이 -3.62 로 1.96 이상으로 나타나 유의하며. 표준적재치가 남 -0.53 , 여 -0.22 로 나타나 남성의 경우 여성보다 호기심과 아트제 품에 대한 부정적 감정 사이에 더 영향력이 크 다는 것을 알 수 있다. 가설6-7(비대중적 선택 $\rightarrow$ 긍정적 감정)은 $\Delta \chi^{2}=3.42$ 로 3.841 에 가까 우나 그에 미치지 못하여 조절효과가 없는 것 으로 보며. 가설6-8(비대중적 선택 $\rightarrow$ 환기)은 $\Delta \chi^{2}=1.45$ 로 조절효과가 없는 것을 알 수 있 다. 가설6-9(비대중적 선택 $\rightarrow$ 부정적 감정)은 $\Delta \chi^{2}=7.36$ 로 나타나 유의한 차이가 있음을 보 여준다. $\mathrm{t}$ 값이 4.42 로 나타나 유의하며. 표준적 재치가 남 0.44 , 여 0.08 로 나타나 여성보다 남 성의 경우 독특성 추구성향 중 비대중적 선택 과 아트제품에 대한 부정적 감정 사이에 영향 을 더 크게 받는다는 것을 알 수 있다. 창의적 선택성향과 비대중적 선택성향의 경우, 부정적 감정과의 관계에서 성별 차이가 있었다. 이는 남성의 창의적 선택성항을 높을수록 부정적 감 정이 여성보다 더 영향을 미치는 것으로 나타 나 자신을 표현하고자 하는 욕구가 크고, 집단 의 규칙에 벗어나고자 하는 욕구가 큰 남성일 수록 아트 제품에 대한 부정적 감정이 여성에 비해 크다는 것을 알 수 있다.

가설6-10(유사성 회피 $\rightarrow$ 긍정적 감정), 가설 6-11(유사성 회피 $\rightarrow$ 환기), 가설6- 12 (유사성 회피 $\rightarrow$ 부정적 감정)의 카이제곱차가 각각 0.16. 0.22 . 0.17 로 모두 카이제곱의 차가 거의 없는 것으로 나타나 조절효과가 없음을 알 수 있다. 유사성 회피 성향이 소비자의 감정에 영 향을 미칠 것으로 보았으나. 어떠한 영향도 미
치지 않는 것으로 나타났다. 이는 아트 제품이 아니어도 유사성 회피 성향을 해결할 수 있으 며. 콜라보레이션 제품은 유사성 회피보다는 창 의적 선택이나 비대중적 선택을 만족시키는데 더 효과적인 것을 알 수 있다.

\section{V. 결 론}

\section{1 연구 요약}

많은 기업에서 마케팅이나 광고를 할 때 아트 를 활용한 아트마케팅을 선보이고 있다. 기존의 명화나 아티스트들과 협업한 새로운 작품을 제 품에 접목하거나, 마케팅에 활용하는 경우가 늘 어나는 추세이다. 따라서 본 연구는 아트마케팅 에 대해 전반적으로 살펴보고, 아트를 받아들이 는 소비자의 개인성향에 대해 알아보았다. 개인 성향 중에서도 소비자의 독특성 추구성향과 호 기심은 새로운 자극에 민감하게 반응하는 개인 특성으로 아트제품을 새로운 자극으로 생각하 고 독특성 추구성향과 호기심이 많은 소비자일 수록 아트제품에 대한 호감도가 증가할 것으로 본다. 따라서 본 연구는 개인특성인 호기심과 독특성 추구성향이 아트제품에 대한 소비자의 감정반응에 미치는 영향과 아트제품에 대한 소 비자의 감정과 구매의도에 미치는 영향을 알아 보았다. 그리고 성별에 따라 개인특성과 소비자 의 감정 사이에 미치는 영향도 달라질 것으로 예측하고 성별의 조절효과를 살펴보았다.

연구결과. 개인특성 중 호기심은 긍정적 감정 에 정의 영향을 미치며, 환기와 부정적 감정에 
는 영향을 미치지 않는 것으로 나타났다. 독특 성 추구성향 중 창의적 선택은 긍정적 감정과 환기에 정의 영향을 미치며. 부정적 감정에도 부의 영향을 미치는 것으로 나타났다. 독특성 추구성향 중 비대중적 선택은 긍정적 감정에는 거의 영향이 없는 것으로 나타났으며. 환기와 부정적 감정에는 유의한 것으로 나타났다. 그리 고 독특성 추구성향 중 유사성 회피는 소비자 의 감정에 어떠한 영향도 미치지 않는 것으로 나타났다. 그리고 성별에 따른 차이를 살펴본 결과. 호기심과 소비자의 감정 사이에는 조절효 과가 없었으며. 유사성 회피와 감정 간에도 조 절효과가 없었다. 그러나 창의적 선택과 부정적 감정 간에, 비대중적 선택과 부정적 감정 간에 는 남녀 간의 차이가 있었다. 자신의 정체성을 표현하고자 하는 욕구에 대해서 남성이 여성보 다 더 부정적인 감정이 높으며, 집단의 규칙을 벗어난 제품을 선택하거나 사용하고자 하는 욕 구에 대해서도 남성이 여성에 비해 부정적 감 정이 크다는 것을 알 수 있다.

\section{2 시사점 및 한계점}

본 연구에서의 시사점은 이론적 시사점과 실 무적 시사점으로 나누어 볼 수 있다. 먼저 이론 적 시사점을 제시하면 다음과 같다. 첫째, 아트 콜라보레이션 제품에 관한 선행연구에서는 일 반제품과 아트 콜라보레이션 제품에 대한 비교 연구에 그친 반면에 본 연구에서는 개인특성이 아트 콜라보레이션 제품에 대한 소비자에 미치 는 감정과 그 감정이 구매의도로 이어지는 구 매결정의 전 과정을 보여주어 소비자의 구매행 동을 세부적이고 구체적인 접근을 하였다는 점
에서 본 연구의 시사점이 크다고 할 수 있다. 둘째. 개인특성인 호기심과 독특성 추구성향 이 소비자의 감정에 미치는 영향을 연구하였는 데. 특히 독특성 추구성향을 창의적 선택. 비대 중적 선택, 유사성 회피 세 가지 차원으로 나누 어 다양한 소비자 집단을 세분화하여 연구함에 의의를 둘 수 있다. 본 연구는 개인특성이라는 다소 주관적이지만 새로운 소비자 집단을 구분 할 수 있음을 제시하고 그 집단의 특성을 살펴 볼 수 있다는데 의의가 있다고 본다.

셋째, 아트 콜라보레이션 제품에 대한 감정이 남녀에 따라 차이가 있음을 보여주었다. 아트 콜라보레이션은 패션제품으로 시작되어 산업전 반에 확장되고 있는데 이를 받아들이는 남녀의 차이를 조절변수로 연구하여 검증하고 있다는 데 의의를 둘 수 있다.

마케팅 측면의 실무적 시사점을 다음과 같이 제시할 수 있다. 첫째, 호기심이 긍정적 감정에 정의 영향이 나타났다. 호기심은 새로운 감각경 험과 새로운 정보나 지식을 획득하려는 욕구를 뜻하는데 이러한 새로운 것을 추구하고자 하는 욕구는 아트 콜라보레이션 제품에 대해 긍정적 인 감정을 유발할 수 있음을 보여준다. 따라서 기업은 제품 개발시 소비자의 호기심을 유발시 키는 새로운 디자인에 힘써야 하며. 광고홍보활 동에 있어서도 새로운 전략을 시도하여 소비자 의 호기심 유발에 집중해야 할 것이다.

둘째. 개인특성의 독특성 추구성향 중 창의적 선택은 자신의 정체성을 표현하고자 하는 욕구 로 긍정적 감정과 환기에 정의 영향을 미치며. 부정적인 감정에는 부의 영향을 미치는 결과를 보여주었다. 이는 콜라보레이션 제품을 선택하 려는 많은 사람들이 자신의 정체성 표현욕구가 
높다는 것을 알 수 있다. 독특성 추구성향 중에 서도 자신의 정체성을 표현하고자 하는 욕구가 높은 사람이 아트 제품을 이용하여 자신의 정 체성을 표현할 수 있도록 다양한 아트 제품을 선보이며, 한정된 양만 생산하여 공급함으로써 자신만의 스타일을 연출할 수 있도록 해야 할 것이다. 앞으로도 지속적으로 예술가들과 콜라 보레이션 활동을 하여 소비자의 감성을 자극하 며. 정체성 표현이 가능한 아트제품을 생산해야 할 것이다.

셋째, 독특성 추구성향 중 유사성 회피는 긍 정적 감정. 환기. 부정적 감정에 거의 영향을 미치지 않는 것으로 나타났다. 유사성 회피 욕 구가 높은 사람은 긍정적 감정. 환기가 정의 영 향을 미칠 것으로 보았으나. 어떠한 영향도 미 치지 않는 것으로 나타났다. 굳이 아트 콜라보 레이션 제품이 아니어도 유사성 회피 성향을 해결할 수 있으며. 아티스트들과 콜라보레이션 제품은 유사성 회피보다는 창의적 선택이나 비 대중적 선택을 만족시키는데 더 유용함을 알 수 있다. 따라서 단순히 남들과 똑같은 것을 싫 다는 소비자의 욕구보다는 정체성 표현 욕구와 준거집단에서 자신이 돋보이려는 성향을 고려 하여 아트 콜라보레이션 제품을 생산해야 할 것이다.

넷째, 성별에 따라 아트 콜라보레이션 제품에 대한 반응은 유의한 차이는 나지 않았다. 유의 하지 않지만, 다소 차이를 보였다. 여성의 경우, 아트와 패션 모두에 관심이 높기 때문에 아트 제품에 대한 호기심과 독특성 추구성향이 높을 수록 아트 제품에 대한 긍정적 감정 및 환기에 정의 영향이 미쳤으며, 남성의 경우 호기심 및 독특성 추구성향과 부정적 감정 간의 관계에서
만 유의한 것으로 나타나 패션과 아트 모두 여 성에 비해 관심도가 다소 떨어지는 것을 알 수 있다. 현재 아트마케팅 전략은 패션뿐만 아니라 산업 전반에 걸쳐 확장되고 있는데. 남성들의 관심이 아직 여성만큼은 아니지만 점차 증가하 고 있기 때문에 그에 맞는 전략이 필요하다. 따 라서 성별에 따른 통계적으로 유의하지 않았지 만. 제품의 디자인이나 예술에 대한 남성들의 관심도가 높아짐을 알 수 있다. 따라서 여성 소 비자뿐만 아니라 남성의 호기심이나 독특성 추 구성향을 자극하는 마케팅을 실행하면 더욱 효 과가 좋을 것을 시사하고 있다. 남성들도 여성 들 못지 않게 아트 콜라보레이션 제품에 대해 관심을 가지며, 아트 콜라보레이션 제품에 대한 관심이 많은 것을 본 연구를 통해 알 수 있었 다. 기업은 트렌드에 뒤떨어지지 않으려는 남성 들의 관심을 끄는 마케팅이 필요하다고 보고 본 연구의 실무적 시사점을 제시한다.

본 연구의 향후 미래 연구 제시 및 한계점은 다음과 같다. 첫째. 본 연구의 대상은 대부분이 20 대 초반의 학생이다. 향후 연구에서는 20 대의 젊은층보다 중년층에서는 아트 콜라보레이션 제 품에 대해 어떤 감정을 가지고 있으며, 구매의 도에는 어떠한 영향을 미치는지 살펴볼 수도 있다. 둘째, 본 연구에서는 아트 콜라보레이션 제품에 미치는 여러 개인 특성 중에서 독특성 추구성향과 호기심만을 대상으로 연구하였다. 향후 연구에서는 혁신성이나 다양성 추구성향. 신기성 추구성향과 같은 여러 개인 특성이 미 치는 영향에 관해 연구해 볼 수도 있으며. 아트 제품의 특성이 소비자의 감정에 미치는 영향에 대해 살펴볼 수 있겠다. 본 연구에서는 이와 같 은 여러 상황이나 변수들을 모두 포함시키기에 
다소 무리가 있어 제한적인 상황에 연구를 한 점이 한계점이라 할 수 있다.

〈논문 접수일: 2011. 10. 16〉 〈1차 수정일: 2012. 04. 20〉 〈게재 확정일: 2012. 04. 26〉

\section{참고문헌}

김민선(2010) 아트 콜라보레이션을 적용한 상업 공간의 $\mathrm{VMD}$ 특성 연구. 국민대학교 디자인 대학원 전시디자인 전공 석사학위 논문 김은영, 김윤경. 김연숙(2002) Gender differences in perception of utilitarian and Hedonic gift attributes among American consumers, 한 국가정학회지, 20(4),127-133

김정현(2009) 아트 광고가 소비자 반응에 미치

는 효과, 홍보학연구, 13(1), 97-122

김한구, 정보희, 주우진(2011) 명화에서 유발된 감정이 차용된 제품과 제품속성 평가에 미

치는 영향, 한국마케팅저널, 13(2), 99-128 문신애(2010) 패션디자인의 아트 콜라보레이션 에 관한 연구 -국내외 패션 브랜드의 사례 분석을 중심으로-, 홍익대학교 대학원 의상 디자인학과 석사학위논문 서문식, 김상희(2002) 성별에 따른 인터넷 쇼핑 상황에서의 감정적 반응이 쇼핑행동에 미치

는 영향, 마케팅과학연구, 9, 101-128 서문식, 김상희(2004) $\mathrm{e}$-서비스 스케이프와 고 객의 감정적 반응 및 행동과의 관계. 경영학 연구, 33(1). 205-239 손준상(2009) 인지초점과 감정초점이 $\mathrm{DMB}$ 휴대
폰에 대한 태도와 구매의도에 미치는 영향. 한국컴퓨터정보학회 14(9), 195-204 유미연(2008) 예술주입이 제품평가에 미치는 영 향: 이미지 친숙도와 적합성을 중심으로. 고 려대학교 석사학위 경영학과 윤지연(2007) 아트마케팅이 소비자의 심리적. 행 동적 반응에 끼치는 영향에 관한 연구: 순 수예술 속성의 응용을 중심으로, 서울대학 교 경영학과 석사학위논문 이경화(2008) 아트마케팅 개념을 적용한 공간디 자인의 연출특성에 관한 연구, 홍익대 학술, 이동철, 박옥련, 김주희, 이현지(2008) 글로벌 시

대의 문화 마케팅 전략. 마케팅, $42(7)$ 장원(2007), 예술을 활용한 기업제품 마케팅의 관계 성과연구, 중앙대학교 석사학위논문 전경숙, 박혜정(2005), 패션성향과 소비자 독특 성 욕구가 명품구매의도에 미치는 영향, 한 국의류학회지, 29(2), 231-241 정혜경(1998) 어린이 시장의 특성에 관한 연구, 청주대학교 대학원 석사논문

Berlyne, D. E.(1957) Attention to change, conditioned inhibition (SIR) and stimulus satiation, British Journal of Psychology. 1957. 48. $138-140$

Bloch. P. H.(1995) Seeking the Ideal Form: Product Design and Consumer Response. Journal of Marketing. 59(July), 16-29

Brizendine, L.(2007) The Female Brain. New York: Broadway Books

Cramphorn, M. F.(2011) Gender effects in advertising, International Journal of Market Research, 53(2), 147-170

Davis, L. Wang. S., Lindridge, A.(2008) Culture 
influences on emotional responses to online store atmospheric cues, Journal of Business Research, 61, 806-812

Sporre, Dennis J.(2003) Perceiving the Arts: an introduction to the humanities, 7th ed. PrenticeHall

Donovan, R. J., Rossiter, J. R.(1982) Store atmosphere: an environmental psychology approach, Journal of retailing. 58(1), 34-57

Eroglu, S. A., Karen A. M., Lenita M. D.(2003) Empirical testing of a model of online store atmospherics and shopper responses, Psychology \& Marketing, 20(2), 139-150

Foxall, G. R., M. M. Yani-de-Soriano(2005) Situational Influence on Consumers' Attitudes and Behavior. Journal of Business Research, 58, 518-525

Fillis, I.(2011) The evolution and development of arts marketing research, Arts Marketing: An International Journal. 1(1), 11-25

Fishbein, M.. Ajzen, I.(1975) Belief. Attitude, Intention and Behavior and Introduction to Theory and research. Reading. MA: AddisonWesley

Hagtvedt. H.. Patrick, V. (2008). The influence of art infusion on the perception and evaluation of consumer products. Journal of Marketing Research, 45(3), 379-389

Heslop, L. A.. Wall, M.(1985) Differences between men and women in the country of origin product images, Administrative Science Associations of Canada Proceedings, Montreal. Canada, 148-158
Kron. J.(1983) Home-psych: the social psychology of home and decoration. New York: Potter

Litman, J. A., Spielberger, C. D.(2003) The measurement of epistemic curiosity and its diversive and specific components. Journal of Personality Assessment 80, 75-86

Loewenstein, G. (1994) The Psychology of $\mathrm{cu}^{-}$ riosity: A review and reinterpretation, $P_{S y}-$ chological Bulletin. 116(1), 75-98

Lynn. M.. Harris.J.(1997) Individual differences in the pursuit of self-uniqueness through consumption, Journal of Applied Social Psychology, 27(21), 1861-1883

Mehrabian, A., Russell, J. A.(1974) An Approach to Environmental Psychology, MIT Press. Cambrige, MA.

Meyer-Levy, J.(1989) Gender differences in information processing: a selectivity hypothesis. In Cafferata, P. C. and Tybout. A. M. (Eds). Cognitive and affective responses to advertising. Lexington Books, 219 260 Moir, A., Jessel, D.(1991) Brain Sex - The Real Differences between Men and Women. New York: Delta

Mummalaneni, V.(2005) An empirical investigation of Website characteristics, consumer emotional states and on-line shopping behaviors, Journal of Business Research. 58. $526-532$

Veryzer. R. W.(1999) A nonconscious processing explanation of consumer response to product design, Psychology \& Marketing, 16 
(6), 497-522

Snyder, C. R.(1992) Product scarcity by need for uniqueness interaction: a consumer catch22 carousel?. Basic and Applied Social Psychology, 13(1), 9-24

Snyder, C. R., Fromkin, H. L.(1977) Abnormality as a positive characteristic: the development and validation of a scale measuring need for uniqueness, Journal of Abnormal Psychology, 86, 518-527

Snyder, C. R.. Fromkin, H. L.(1980) Uniqueness: The human pursuit of difference. New York: Plenum
Stell, R., Paden, N.(1999) Vicarious exploration and catalog shopping: a preliminary investigation, Journal of Consumer Marketing. 16(4), 332-346

Tian T. K.. Bearden. W. O., Hunter, G. I. (2001) Consumers' need for uniqueness scale development and validation, Journal of Consumer Research, 28 (June), 50-66

Voss, H. G., Keller. H.(1983) Curiosity and exploration: theories and results. New York, NY: Academic Press

Watson, D., Clark, L. A., Tellegen, A.(1988), Toward a consensual structure of mood. Psychological Bulletin, 98, 291-235 


\title{
The Effect of Curiosity and Need for Uniqueness on Emotional Responses to Art Collaborated Products including Moderating Effect of Gender
}

\author{
Seon Hee $\mathrm{Ju}^{*}$ \\ Dong-Mo Koo**
}

\begin{abstract}
Companies recently introduce art collaborated products incorporating culture into a product. Art collaborated products include incorporating famous movies and/or design of an artist into a newly launched product. The introduction of art collaborated products are gradually increasing. However, research for this trend is relatively scarce. Although research concerning design has discussed a number of different factors as playing a role in influencing responses to design including culture. fashion, innate preferences, etc.), only limited attention has been paid to the processes by which consumers generate responses to product designs.

People with different characteristics may respond differently. When people encounter these art products, they may become curious, may think that these products are unique, novel and innovative. People tend to show different levels of curiosity when they encounter new and novel objects, which they have rarely seen or experienced. Curiosity is defined as a desire for acquiring new knowledge and new sensory experience. Previous studies demonstrated that curiosity motivates individuals to engage in exploratory behaviors. People also show different levels of need for uniqueness, which is defined as being different from others or becoming distinctive among a larger group. Individual's need for uniqueness results from signals conveyed by the material objects that individuals choose to display. Recently, researcher have developed the need for uniqueness with three distinct constructs. These three concepts include creative choice, unpopular choice, and avoidance of similarity. Creative choice is a trait tendency of an individual by expressing or differentiating himself from others through consumptions of unique products. Unpopular choice is related to an individual's tendency to consume products, which deviates from group norms. Avoidance of similarity is linked to the avoidance of consumption behavior of products that are not famous. Past research implies that people with different
\end{abstract}

* Ph. D. Student, School of Management. Kyungpook National University

** Professor, School of Management, Kyungpook National University 
levels of need for uniqueness show different motivational processes.

Previous research also demonstrates that different customer emotions may be derived when consumers are exposed to these art collaborated products. Research tradition has been investigated three different emotional responses such as pleasure, arousal, and dominance. Pleasure is defined as the degree to which a person feels good, joyful, happy, or satisfied in a situation. Arousal is defined as the extent to which a person feels stimulated, active, or excited. Dominance is defined as the extent that a person feels powerful vis-a-vis the environment that surrounds him/her. Previous research show that complex, speedy, and surprising stimuli may excite consumers and thus make them more pleased and engaged in their approach behavior. However, the current study identified these emotional responses as positive emotion, negative emotion, and arousal. These derived emotions may lead consumers to approach and/or avoidance behaviors. In addition, males and females tend to respond differently when they are exposed to art collaboration products.

Building on this research tradition, the current study aims to investigate the inter-relationships between individual traits such as curiosity and need for uniqueness and individual's emotional responses including positive and negative emotion and arousal when people encounter various art collaborated products. Emotional responses are proposed to influence purchase intention. Additionally, previous studies show that male and females respond differently to similar stimuli. Accordingly, gender difference are proposed to moderate the links between individual traits and emotional responses.

These research aims of the current study may contribute to extending our knowledge in terms of (1) which individual characteristics are related to different emotions, and (2) how these different emotional responses inter-connected to future purchase intention of arts collaborated products. In addition. (3) the different responses to these arts collaborated products by males and females will guide managers how to concoct different strategies to these segments.

The questionnaire for the present study was adopted from the previous literature and validated with a pilot test. The survey was conducted in Daegu, a third largest city in South Korea, for three weeks during June and July 2011. Most respondents were in their twenties and thirties. 350 questionnaires were distributed and among them 300 were proved to be valid (valid response rate of 85.7\%). Survey questionnaires from valid 300 respondents are used to test hypotheses proposed. The structural equation model (SEM) was used to validate the research model. The measurement and structural model was tested using LISREL 8.7. The measurement model test demonstrated that consistency, convergent validity, and discriminat validity of the measurement items were acceptable.

The results from the structural model demonstrate that curiosity has a positive impact on positive emotion, but not on negative emotion and arousal. Need for uniqueness has three different 
sub-concepts such as creative choice, unpopular choice, and avoidance of similarity. The results show that creative choice has a positive effect on arousal and positive emotion, but has a negative impact on negative emotion. Unpopular choice has a positive effect on arousal, but on neither positive nor negative emotions. Avoidance of similarity has no impact on neither emotions nor arousal. The results also demonstrated that gender has a moderating influence. Males show more negative emotion to creative and unpopular choices. Implications and future research directions are discussed in conclusion.

Key words: Curiosity, Need for Touch, Emotion, Purchase Intention, Gender 